\title{
Zero-, mono- and diperiodic uranyl ion complexes with the diphenate dianion: influences of transition metal ion coordination and differential $\mathrm{U}^{\mathrm{VI}}$ chelation $\dagger$
}

\author{
Pierre Thuéry, ${ }^{* a}$ Youssef Atoini ${ }^{b}$ and Jack Harrowfield ${ }^{* b}$
}

Diphenic acid ( $\left.\mathrm{H}_{2} \mathrm{dip}\right)$ has been used to synthesize nine homo- or heterometallic uranyl ion complexes under solvohydrothermal conditions. The diphenate ligand $\operatorname{dip}^{2-}$ adopts different coordination modes, mixtures of $\kappa^{2}-O, O^{\prime}-$ chelation by individual carboxylate groups, chelation involving both carboxylate groups, and bridging, resulting in different associations of the cations present. $\left[\mathrm{UO}_{2}(\operatorname{dip})\right](\mathbf{1}),\left[\mathrm{UO}_{2}(\operatorname{dip})(\right.$ bipy)$)(\mathbf{2})$, and $\left[\mathrm{UO}_{2}(\operatorname{dip})(\mathrm{phen})\right](\mathbf{3})$ crystallize as monoperiodic coordination polymers, complex 1 with the bridging and both chelation modes of the ligand, and 2 and 3 with only the bis- $\kappa^{2}-O, O^{\prime}$-chelated mode and further chelation by $2,2^{\prime}$-bipyridine (bipy) or 1,10-phenanthroline (phen). The two isomorphous complexes $\left[\mathrm{H}_{2} \mathrm{NMe}_{2}\right]_{2}\left[\left(\mathrm{UO}_{2}\right)_{2}(\operatorname{dip})_{3}\right]$ (4) and $\left[\left(\mathrm{UO}_{2}\right)_{2} \mathrm{Ag}_{2}(\mathrm{dip})_{3}\left(\mathrm{H}_{2} \mathrm{O}\right)\left(\mathrm{CH}_{3} \mathrm{CN}\right)\right](5)$ display ladder-like monoperiodic arrangements with the hydrogen bonded $\mathrm{H}_{2} \mathrm{NMe}_{2}{ }^{+}$or carboxylate-bound, decorating $\mathrm{Ag}^{+}$cations occupying similar positions within the chains. [Ni $(R, S-$ $\mathrm{Me}_{6}$ cyclam $\left.)\left(\mathrm{H}_{2} \mathrm{O}\right)_{2}\right]\left[\mathrm{UO}_{2}(\operatorname{dip})_{2}\right]$ (6) contains a discrete dianionic mononuclear species, while $\left[\left(\mathrm{UO}_{2}\right)_{2}(\mathrm{dip})_{2}(\mathrm{Hdip})_{2} \mathrm{Ni}(\mathrm{cyclam})\right] \cdot 2 \mathrm{H}_{2} \mathrm{O} \cdot 2 \mathrm{CH}_{3} \mathrm{CN}(7)$ crystallizes as a monoperiodic, heterometallic polymer, with further formation of layers through reciprocal hydrogen bonding of the carboxylic acid groups. A discrete dinuclear dianionic complex is present in $\left[\mathrm{Cu}\left(R, S-\mathrm{Me}_{6}\right.\right.$ cyclam $\left.)\right]\left[\mathrm{UO}_{2}(\operatorname{dip})\left(\mathrm{NO}_{3}\right)\right]_{2}(\mathbf{8})$, which crystallizes together with $\left[\left(\mathrm{UO}_{2}\right)_{3}(\mathrm{dip})_{4} \mathrm{Cu}\left(R, S-\mathrm{Me}_{6}\right.\right.$ cyclam $\left.)\left(\mathrm{H}_{2} \mathrm{O}\right)_{2}\right] \cdot 6 \mathrm{H}_{2} \mathrm{O}(9)$, a diperiodic assembly in which uranyl-containing dimeric units are assembled in chains through diaxial carboxylate coordination of $\mathrm{Cu}\left(R, S-\mathrm{Me}_{6} \mathrm{cyclam}\right)^{2+}$ cations, further bridging by uranyl cations generating a network with the fes topology. Complexes $\mathbf{3}, \mathbf{4}$ and $\mathbf{5}$ have uranyl emission spectra displaying the usual vibronic fine structure, while uranyl emission in $\mathbf{7}$ is largely quenched.

${ }^{a}$ NIMBE, CEA, CNRS, Université Paris-Saclay, CEA Saclay, 91191 Gif-sur-Yvette, France; E-mail: pierre.thuery@cea.fr

bISIS, Université de Strasbourg, 8 allée Gaspard Monge, 67083 Strasbourg, France; E-mail: harrowfield@unistra.fr † CCDC 1958810-1958818. 


\section{Introduction}

The diphenyl/biphenyl skeleton is one among the many carboxylate-bearing organic platforms which have been used in the synthesis of uranyl-organic complexes, coordination polymers and frameworks. ${ }^{1-5}$ Most occurrences of this platform involve the linear 4,4'-diphenyldicarboxylate ligand, ${ }^{6-10}$ which has provided access to several novel systems, among which may be mentioned complexes displaying $\mathrm{U}=\mathrm{O}-\mathrm{U}$ oxo-bonding, ${ }^{7}$ polycatenation, ${ }^{8}$ or single-crystal-to-singlecrystal phase transitions ${ }^{10}$ (polycatenation was also reported with the related 2,2'-bipyridine5,5'-dicarboxylate ligand $\left.{ }^{11}\right)$. With two more carboxylate groups, 3,3',4,4'diphenyltetracarboxylate was also used and allowed formation of a triperiodic framework. ${ }^{12}$ These particular ligands generally retain a quasi-planar geometry of the diphenyl moiety, but this is no longer true when the carboxylate substituents are located closer to one another, as in 1,1'-diphenyl-2,2',6,6'-tetracarboxylate, in which steric crowding results in quasi-perpendicular positioning of the two aromatic rings expected to favour triperiodic arrays, and which has actually been shown to form mono-, di-, and triperiodic uranyl complexes. ${ }^{13}$ Although 2,2'bipyridine-3,3'-dicarboxylate and 1,1'-diphenyl-6,6'-dinitro-2,2'-dicarboxylate, both with tilted aromatic rings, have also been used in this context, ${ }^{14-16}$ no uranyl ion complex has yet been reported with the simpler ligand resulting from deprotonation of diphenic acid (1,1'-diphenyl2,2'-dicarboxylic acid, $\mathrm{H}_{2} \mathrm{dip}$ ). In order to expose the possible coordination modes of this ligand toward the uranyl ion and thus its potential for the creation of new coordination arrays, we have synthesized nine homo- or heterometallic complexes under solvo-hydrothermal conditions in the presence of various cosolvents, coligands and additional cations/counterions. These complexes have been characterized by their crystal structure and, for some of them, their emission spectrum in the solid state. Although low-periodicity compounds are the general outcome of these reactions, proper choice of the additional cation has allowed the formation of 
a diperiodic assembly. The coordination mode of the ligand also displays a degree of variability, including different bridging and chelating geometries.

\section{Experimental}

\section{Synthesis}

Caution! Uranium is a radioactive and chemically toxic element, and uranium-containing samples must be handled with suitable care and protection.

$\mathrm{UO}_{2}\left(\mathrm{NO}_{3}\right)_{2} \cdot 6 \mathrm{H}_{2} \mathrm{O}$ (depleted uranium, R. P. Normapur, 99\%) and $\mathrm{AgNO}_{3}$ were purchased from Prolabo. Diphenic acid and 1,10-phenanthroline were from Aldrich, and 2,2'bipyridine was from Fluka. [Ni(cyclam) $\left.\left(\mathrm{NO}_{3}\right)_{2}\right],\left[\mathrm{Ni}\left(R, S-\mathrm{Me}_{6}\right.\right.$ cyclam $\left.)\left(\mathrm{NO}_{3}\right)_{2}\right]$, and $[\mathrm{Cu}(R, S-$ $\mathrm{Me}_{6}$ cyclam $\left.)\left(\mathrm{NO}_{3}\right)_{2}\right]$ were synthesized as described in previous work. ${ }^{17,18}$ Elemental analyses were performed by MEDAC Ltd. at Chobham, UK. For all syntheses, the mixtures in demineralized water/organic solvent were placed in $10 \mathrm{~mL}$ tightly closed glass vessels and heated at $140{ }^{\circ} \mathrm{C}$ under autogenous pressure, and the crystals were grown in the hot, pressurized solutions.

$\left[\mathrm{UO}_{2}(\mathrm{dip})\right](\mathbf{1}) . \mathrm{H}_{2} \operatorname{dip}(25 \mathrm{mg}, 0.10 \mathrm{mmol})$ and $\mathrm{UO}_{2}\left(\mathrm{NO}_{3}\right)_{2} \cdot 6 \mathrm{H}_{2} \mathrm{O}(50 \mathrm{mg}, 0.10 \mathrm{mmol})$ were dissolved in water $(0.8 \mathrm{~mL})$ and acetonitrile $(0.2 \mathrm{~mL})$. Yellow crystals of complex 1 were obtained in low yield within one week.

[UO 2 (dip)(bipy)] (2). $\mathrm{H}_{2} \operatorname{dip}(25 \mathrm{mg}, 0.10 \mathrm{mmol}), \mathrm{UO}_{2}\left(\mathrm{NO}_{3}\right)_{2} \cdot 6 \mathrm{H}_{2} \mathrm{O}(35 \mathrm{mg}, 0.07$ $\mathrm{mmol}$ ), $\mathrm{AgNO}_{3}(17 \mathrm{mg}, 0.10 \mathrm{mmol}$ ), and 2,2'-bipyridine (32 $\mathrm{mg}, 0.20 \mathrm{mmol}$ ) were dissolved in water $(0.8 \mathrm{~mL})$ and acetonitrile $(0.2 \mathrm{~mL})$. Yellow crystals of complex 2 were obtained in low yield within one week.

[UO ${ }_{2}$ (dip)(phen)] (3). $\mathrm{H}_{2} \operatorname{dip}(25 \mathrm{mg}, 0.10 \mathrm{mmol}), \mathrm{UO}_{2}\left(\mathrm{NO}_{3}\right)_{2} \cdot 6 \mathrm{H}_{2} \mathrm{O}(35 \mathrm{mg}, 0.07$ mmol), $\mathrm{Pb}\left(\mathrm{NO}_{3}\right)_{2}(33 \mathrm{mg}, 0.10 \mathrm{mmol})$, and 1,10-phenanthroline (18 $\left.\mathrm{mg}, 0.10 \mathrm{mmol}\right)$ were dissolved in water $(0.8 \mathrm{~mL})$ and acetonitrile $(0.2 \mathrm{~mL})$. Yellow crystals of complex 3 were 
obtained within one week ( $32 \mathrm{mg}, 66 \%$ yield based on $\mathrm{U}$ ). Anal. calcd for $\mathrm{C}_{26} \mathrm{H}_{16} \mathrm{~N}_{2} \mathrm{O}_{6} \mathrm{U}$ : C, 45.23; H, 2.34; N, 4.06. Found: C, 45.08; H, 2.38; N 4.18\%.

$\left[\mathrm{H}_{2} \mathrm{NMe}_{2}\right]_{2}\left[\left(\mathrm{UO}_{2}\right)_{2}(\mathrm{dip})_{3}\right]$ (4). $\mathrm{H}_{2} \operatorname{dip}(25 \mathrm{mg}, 0.10 \mathrm{mmol})$ and $\mathrm{UO}_{2}\left(\mathrm{NO}_{3}\right)_{2} \cdot 6 \mathrm{H}_{2} \mathrm{O}(50 \mathrm{mg}$, $0.10 \mathrm{mmol})$ were dissolved in water $(0.8 \mathrm{~mL})$ and DMF $(0.2 \mathrm{~mL})$. Yellow crystals of complex 4 were obtained within three days (16 mg, 34\% yield based on U). Anal. calcd for $\mathrm{C}_{46} \mathrm{H}_{40} \mathrm{~N}_{2} \mathrm{O}_{16} \mathrm{U}_{2}:$ C, 40.84; H, 2.98; N, 2.07. Found: C, 40.36; H, 2.87; N 2.09\%.

$\left[\left(\mathrm{UO}_{2}\right)_{2} \mathrm{Ag}_{2}(\operatorname{dip})_{3}\left(\mathrm{H}_{2} \mathrm{O}\right)\left(\mathrm{CH}_{3} \mathrm{CN}\right)\right](\mathbf{5}) . \mathrm{H}_{2} \operatorname{dip}(25 \mathrm{mg}, 0.10 \mathrm{mmol}), \mathrm{UO}_{2}\left(\mathrm{NO}_{3}\right)_{2} \cdot 6 \mathrm{H}_{2} \mathrm{O}(35$ mg, $0.07 \mathrm{mmol})$, and $\mathrm{AgNO}_{3}(34 \mathrm{mg}, 0.20 \mathrm{mmol})$ were dissolved in water $(0.8 \mathrm{~mL})$ and acetonitrile $(0.2 \mathrm{~mL})$. Yellow crystals of complex 5 were obtained within three days $(22 \mathrm{mg}$, $41 \%$ yield based on $\mathrm{U})$. Anal. calcd for $\mathrm{C}_{44} \mathrm{H}_{29} \mathrm{Ag}_{2} \mathrm{NO}_{17} \mathrm{U}_{2}$ : C, 34.42; H, 1.90; N, 0.91. Found: C, 34.33; H, 1.96; N 0.71\%.

$\left[\mathrm{Ni}\left(R, S-\mathrm{Me}_{6}\right.\right.$ cyclam $\left.)\left(\mathrm{H}_{2} \mathrm{O}\right)_{2}\right]\left[\mathrm{UO}_{2}(\operatorname{dip})_{2}\right] \quad(6) . \quad \mathrm{H}_{2} \operatorname{dip} \quad(25 \quad \mathrm{mg}, \quad 0.10 \quad \mathrm{mmol})$, $\mathrm{UO}_{2}\left(\mathrm{NO}_{3}\right)_{2} \cdot 6 \mathrm{H}_{2} \mathrm{O}(35 \mathrm{mg}, 0.07 \mathrm{mmol})$, and $\left[\mathrm{Ni}\left(R, S-\mathrm{Me}_{6}\right.\right.$ cyclam $\left.)\left(\mathrm{NO}_{3}\right)_{2}\right](23 \mathrm{mg}, 0.05 \mathrm{mmol})$ were dissolved in water $(0.8 \mathrm{~mL})$ and DMF $(0.2 \mathrm{~mL})$. Yellow crystals of complex 6 were obtained in low yield within three days.

$\left[\left(\mathrm{UO}_{2}\right)_{2}(\mathrm{dip})_{2}(\mathrm{Hdip})_{2} \mathrm{Ni}(\right.$ cyclam$\left.)\right] \cdot 2 \mathrm{H}_{2} \mathrm{O} \cdot 2 \mathrm{CH}_{3} \mathrm{CN}$ (7). $\mathrm{H}_{2} \operatorname{dip}(25 \mathrm{mg}, 0.10 \mathrm{mmol})$, $\mathrm{UO}_{2}\left(\mathrm{NO}_{3}\right)_{2} \cdot 6 \mathrm{H}_{2} \mathrm{O}(35 \mathrm{mg}, 0.07 \mathrm{mmol})$, and [Ni(cyclam) $\left.\left(\mathrm{NO}_{3}\right)_{2}\right](20 \mathrm{mg}, 0.05 \mathrm{mmol})$ were dissolved in water $(0.8 \mathrm{~mL})$ and acetonitrile $(0.2 \mathrm{~mL})$. Yellow crystals of complex 7 were obtained within three days (15 mg, 32\% yield based on the acid). Anal. calcd for $\mathrm{C}_{70} \mathrm{H}_{68} \mathrm{~N}_{6} \mathrm{NiO}_{22} \mathrm{U}_{2}: \mathrm{C}, 44.72 ; \mathrm{H}, 3.65 ; \mathrm{N}, 4.47$. Found: $\mathrm{C}, 45.18 ; \mathrm{H}, 3.46 ; \mathrm{N} 4.27 \%$.

$$
\left[\mathrm{Cu}\left(R, S-\mathrm{Me}_{6} \text { cyclam }\right)\right]\left[\mathrm{UO}_{2}(\mathrm{dip})\left(\mathrm{NO}_{3}\right)\right]_{2} \quad \text { (8) and } \quad\left[\left(\mathrm{UO}_{2}\right)_{3}(\operatorname{dip})_{4} \mathrm{Cu}(R, S-\right.
$$

$\mathrm{Me}_{6}$ cyclam $\left.)\left(\mathrm{H}_{2} \mathrm{O}\right)_{2}\right] \cdot 6 \mathrm{H}_{2} \mathrm{O}(9) . \mathrm{H}_{2} \operatorname{dip}(25 \mathrm{mg}, 0.10 \mathrm{mmol}), \mathrm{UO}_{2}\left(\mathrm{NO}_{3}\right)_{2} \cdot 6 \mathrm{H}_{2} \mathrm{O}(35 \mathrm{mg}, 0.07$ $\mathrm{mmol})$, and $\left[\mathrm{Cu}\left(R, S-\mathrm{Me}_{6}\right.\right.$ cyclam $\left.)\left(\mathrm{NO}_{3}\right)_{2}\right](24 \mathrm{mg}, 0.05 \mathrm{mmol})$ were dissolved in water $(0.8 \mathrm{~mL})$ and acetonitrile $(0.2 \mathrm{~mL})$. Yellow crystals of complex 8 and purple crystals of complex 9 were obtained together within three days. 


\section{Crystallography}

The data were collected at 100(2) K on a Nonius Kappa-CCD area detector diffractometer ${ }^{19}$ using graphite-monochromated Mo K $\alpha$ radiation $(\lambda=0.71073 \AA)$. The crystals were introduced into glass capillaries with a protective coating of Paratone-N oil (Hampton Research). The unit cell parameters were determined from ten frames, then refined on all data. The data (combinations of $\varphi$ - and $\omega$-scans with a minimum redundancy of 4 for $90 \%$ of the reflections) were processed with HKL2000. ${ }^{20}$ Absorption effects were corrected empirically with the program SCALEPACK ${ }^{20}$ The structures were solved by intrinsic phasing with SHELXT, ${ }^{21}$ expanded by subsequent difference Fourier synthesis and refined by full-matrix least-squares on $F^{2}$ with SHELXL-2014. ${ }^{22}$ All non-hydrogen atoms were refined with anisotropic displacement parameters. The hydrogen atoms bound to oxygen and nitrogen atoms in complexes 5-9 were retrieved from difference Fourier maps (except for those of two free water molecules in 9), and were refined with restraints on bond lengths and angles when necessary, and an isotropic displacement parameter equal to $1.2(\mathrm{NH})$ or $1.5\left(\mathrm{H}_{2} \mathrm{O}\right)$ times that of the attached atom. All the other hydrogen atoms were introduced at calculated positions and were treated as riding atoms with an isotropic displacement parameter equal to 1.2 times that of the parent atom (1.5 for $\mathrm{CH}_{3}$, with optimized geometry). In complex $\mathbf{5}$, the $\mathrm{Ag} 2$ atom is disordered over two sites which were refined with occupancy parameters constrained to sum to unity. Crystal data and structure refinement parameters are given in Table 1. The molecular plots were drawn with ORTEP-3, ${ }^{23}$ and the polyhedral representations with VESTA (Version 3.4.4). ${ }^{24}$ The topological analyses were conducted with ToposPro. ${ }^{25}$ 
Table 1 Crystal data and structure refinement details

\begin{tabular}{|c|c|c|c|c|c|c|c|c|c|}
\hline & 1 & 2 & 3 & 4 & 5 & 6 & 7 & 8 & 9 \\
\hline Chemical formula & $\mathrm{C}_{14} \mathrm{H}_{8} \mathrm{O}_{6} \mathrm{U}$ & $\mathrm{C}_{24} \mathrm{H}_{16} \mathrm{~N}_{2} \mathrm{O}_{6} \mathrm{U}$ & $\mathrm{C}_{26} \mathrm{H}_{16} \mathrm{~N}_{2} \mathrm{O}_{6} \mathrm{U}$ & $\mathrm{C}_{46} \mathrm{H}_{40} \mathrm{~N}_{2} \mathrm{O}_{16} \mathrm{U}_{2}$ & $\mathrm{C}_{44} \mathrm{H}_{29} \mathrm{Ag}_{2} \mathrm{NO}_{17} \mathrm{U}_{2}$ & $\mathrm{C}_{44} \mathrm{H}_{56} \mathrm{~N}_{4} \mathrm{NiO}_{12} \mathrm{U}$ & $\mathrm{C}_{70} \mathrm{H}_{68} \mathrm{~N}_{6} \mathrm{NiO}_{22} \mathrm{U}_{2}$ & $\mathrm{C}_{44} \mathrm{H}_{52} \mathrm{CuN}_{6} \mathrm{O}_{18} \mathrm{U}_{2}$ & $\mathrm{C}_{72} \mathrm{H}_{84} \mathrm{CuN}_{4} \mathrm{O}_{30} \mathrm{U}_{3}$ \\
\hline$M / \mathrm{g} \mathrm{mol}^{-1}$ & 510.23 & 666.42 & 690.44 & 1352.86 & 1535.48 & 1129.66 & 1880.07 & 1492.51 & 2263.06 \\
\hline Crystal system & Triclinic & Monoclinic & Monoclinic & Triclinic & Triclinic & Triclinic & Triclinic & Triclinic & Triclinic \\
\hline Space group & $P_{\overline{1}}$ & $P 2{ }_{1} / n$ & $P 2_{1} / n$ & $P_{\overline{1}}$ & $P_{\overline{1}}$ & $P_{\overline{1}}$ & $P_{\overline{1}}$ & $P_{\overline{1}}$ & $P \overline{1}$ \\
\hline$a / \AA$ & $9.3038(10)$ & $9.6615(5)$ & $9.9607(4)$ & $9.3807(5)$ & $9.4256(5)$ & $9.6239(8)$ & $11.7413(6)$ & $9.4464(8)$ & $9.6248(9)$ \\
\hline$b / \AA$ & $9.3958(8)$ & $12.0553(4)$ & $11.8944(9)$ & $15.4285(7)$ & $15.0290(5)$ & $11.7355(7)$ & $12.9324(7)$ & $9.6422(10)$ & $13.5485(10)$ \\
\hline$c / \AA$ & $9.9840(15)$ & $17.6732(8)$ & $18.5400(16)$ & $16.3847(9)$ & $15.8358(8)$ & $12.0230(10)$ & $13.9484(5)$ & $15.0190(12)$ & $15.1649(16)$ \\
\hline$\alpha^{\prime \circ}$ & $92.354(7)$ & 90 & 90 & $76.348(3)$ & $76.635(3)$ & $61.358(4)$ & $116.738(3)$ & $82.508(5)$ & $88.758(6)$ \\
\hline$\beta /^{\circ}$ & $116.196(5)$ & $92.542(3)$ & $96.404(4)$ & $74.879(3)$ & $78.852(2)$ & $67.648(4)$ & $99.863(3)$ & $73.613(5)$ & $78.287(5)$ \\
\hline$\gamma^{10}$ & $111.110(6)$ & 90 & 90 & $86.421(3)$ & $87.993(3)$ & $80.938(5)$ & $104.484(3)$ & $67.945(4)$ & $82.984(6)$ \\
\hline$V / \AA^{3}$ & $709.40(16)$ & $2056.41(16)$ & $2182.9(3)$ & $2224.6(2)$ & $2141.21(17)$ & $1101.68(16)$ & $1729.92(17)$ & $1215.9(2)$ & $1921.8(3)$ \\
\hline Z & 2 & 4 & 4 & 2 & 2 & 1 & 1 & 1 & 1 \\
\hline Reflections collected & 32551 & 63892 & 116607 & 123754 & 128849 & 59752 & 92782 & 56007 & 95479 \\
\hline Independent reflections & 2687 & 3899 & 4137 & 8441 & 8145 & 4172 & 6561 & 4604 & 7291 \\
\hline Observed reflections $[I>2 \sigma(I)]$ & 2207 & 3311 & 3322 & 6754 & 7000 & 3981 & 5805 & 3761 & 5402 \\
\hline$R_{\text {int }}$ & 0.091 & 0.058 & 0.035 & 0.049 & 0.067 & 0.078 & 0.061 & 0.104 & 0.079 \\
\hline Parameters refined & 190 & 298 & 316 & 599 & 612 & 298 & 473 & 331 & 520 \\
\hline$R_{1}$ & 0.032 & 0.029 & 0.031 & 0.028 & 0.026 & 0.031 & 0.027 & 0.039 & 0.040 \\
\hline$w R_{2}$ & 0.053 & 0.065 & 0.070 & 0.061 & 0.059 & 0.059 & 0.056 & 0.071 & 0.088 \\
\hline$S$ & 0.916 & 1.041 & 1.040 & 1.011 & 1.045 & 1.012 & 1.019 & 0.965 & 1.026 \\
\hline$\Delta \rho_{\min } / \mathrm{e} \AA^{-3}$ & -1.33 & -1.61 & -1.07 & -1.17 & -1.15 & -1.11 & -0.73 & -1.40 & -1.84 \\
\hline$\Delta \rho_{\max } / \mathrm{e}^{-3}$ & 2.10 & 1.91 & 0.89 & 2.07 & 1.06 & 0.79 & 1.19 & 1.55 & 1.17 \\
\hline
\end{tabular}




\section{Luminescence Measurements}

Emission spectra were recorded on solid samples using a Horiba-Jobin-Yvon IBH FL-322 Fluorolog 3 spectrometer equipped with a $450 \mathrm{~W}$ xenon arc lamp, double-grating excitation and emission monochromators $(2.1 \mathrm{~nm} / \mathrm{mm}$ of dispersion; 1200 grooves $/ \mathrm{mm})$ and a TBX-04 single photon-counting detector. The powdered compounds were pressed to the wall of a quartz tube, and the measurements were performed using the right angle mode. An excitation wavelength of $420 \mathrm{~nm}$, a commonly used point although only part of a broad manifold, was used in all cases and the emission was monitored between 450 and $650 \mathrm{~nm}$. The quantum yield measurements were performed by using a Hamamatsu Quantaurus C11347 absolute photoluminescence quantum yield spectrometer and exciting the sample between 300 and $400 \mathrm{~nm}$.

\section{Results and discussion}

\section{Synthesis}

All complexes were synthesized under solvo-hydrothermal conditions at a temperature of 140 ${ }^{\circ} \mathrm{C}$, with the organic cosolvent being acetonitrile for complexes $\mathbf{1}-\mathbf{3}, \mathbf{5}$ and $\mathbf{7 - 9}$, and $\mathrm{N}, \mathrm{N}$ dimethylformamide for $\mathbf{4}$ and $\mathbf{6}$. As commonly found with syntheses performed with DMF as a cosolvent, dimethylammonium cations resulting from solvent hydrolysis are present in complex 4. Apart from this, the only occurrences of the organic solvent in the present series of complexes is as a ligand on $\mathrm{Ag}^{\mathrm{I}}$ in $\mathbf{5}$ and as a solvation molecule in $\mathbf{7}$. It is notable that a nitrate coligand is present in complex 8; although generally displaced by carboxylate donors, nitrate anions are sometimes retained in the uranyl coordination sphere, their presence presumably reflecting subtle influences of solid state interactions on the solubility of the complex. It is notable that crystals of $\mathbf{8}$ were obtained together with crystals of $\mathbf{9}$, in which nitrate is absent. When the intention was to synthesize a homometallic, neutral uranyl complex, the uranyl $/ \mathrm{H}_{2}$ dip ratio in the synthesis was $1: 1$, and this ratio is retained in complex $\mathbf{1}$, while it is $2: 3$ in complex $\mathbf{4}$ due 
to the adventitious presence of dimethylammonium cations. In cases where formation of an anionic uranyl complex was contemplated, the ratio in solution was 7:10, but the expected 2:3 ratio in the solid state was only found in complex 5; complexes $\mathbf{2}$ and $\mathbf{3}$ have the 1:1 ratio due to non-incorporation of the additional cations intended, and the other complexes display different stoichiometries defective in uranyl cations, 1:2 in $\mathbf{6}$ and 7 (the latter incorporating both fully- and mono-deprotonated ligands), and 3:4 in $\mathbf{9}$. Finally, the ratio is $1: 1$ in $\mathbf{8}$, but the complex is nevertheless anionic in this case due to the coordinated nitrate anion. Overall, if association of additional metallic cations to anionic uranyl complexes can be considered generally successful, the control of the finer details, and particularly the stoichiometry, is far less satisfying, and can be seen as a drawback of the otherwise very attractive solvohydrothermal synthesis methods.

\section{Crystal structures}

The complex $\left[\mathrm{UO}_{2}(\mathrm{dip})\right]$ (1) is the simplest in the series, being homometallic and neutral, and with only one uranyl cation and one ligand in the asymmetric unit (Fig. 1). The uranium cation is chelated by one carboxylate group in the $\kappa^{2}-O, O^{\prime}$ mode (four-membered chelate ring), and it is also chelated by binding one oxygen from each of the two carboxylate groups of another diphenate ligand to form a nine-membered chelate ring. Since these two chelation modes will be frequently found in this series of complexes, they will be denoted as modes 1 and 2 respectively, in keeping with former use. ${ }^{13}$ The carboxylate oxygen atom not involved in formation of either of these chelate units forms a bridge to another uranium centre, the combined bonding interactions giving the uranium coordination environment a pentagonal bipyramidal geometry, with unexceptional bond lengths [U-O(oxido) 1.756(4) and 1.761(4) $\AA$, U-O(carboxylato) 2.453(4) and 2.550(5) $\AA$ for mode 1 chelation, and 2.307(2)-2.425(4) $\AA$ for monodentate bonding]. One ligand is thus connected to three metal cations, the two carboxylate 

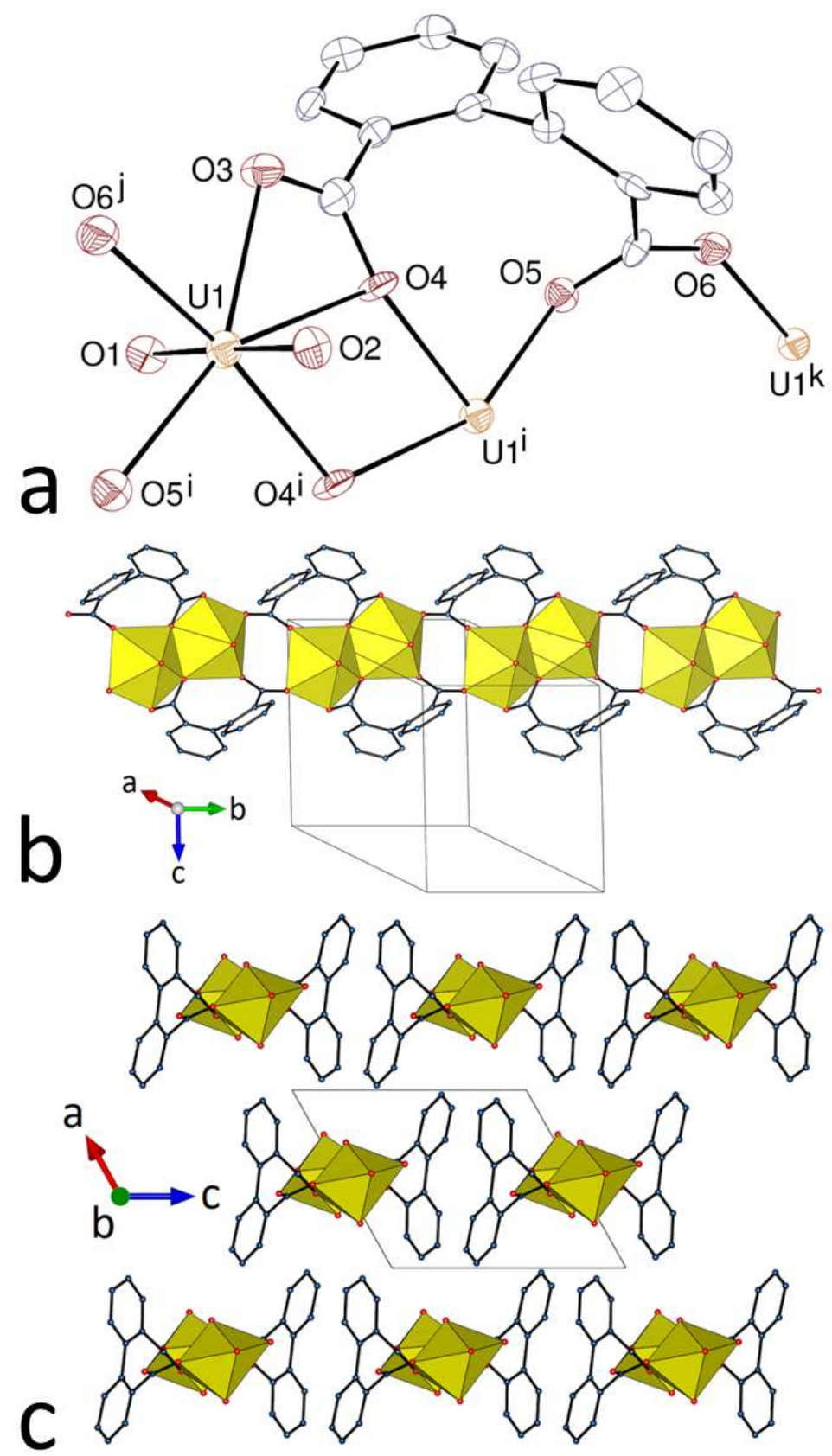

Fig. 1 (a) View of compound 1. Displacement ellipsoids are drawn at the 50\% probability level, and hydrogen atoms are omitted. Symmetry codes: $\mathrm{i}=1-x, 2-y, 2-z ; \mathrm{j}=x, y+1, z ; \mathrm{k}=x, y-1, z$. (b) View of the 1D polymer with uranium coordination polyhedra colored yellow. (c) Packing with the chains viewed end-on.

groups having the $\mu_{2}-\kappa^{2} O, O^{\prime}: \kappa^{1} O^{\prime}$ and syn/anti $\mu_{2}-\kappa^{1} O: \kappa^{1} O^{\prime}$ coordination modes. Despite the twisting of the diphenyl unit, the ready rotation about the $\mathrm{C}-\mathrm{CO}_{2}{ }^{-}$bonds provides a donor array compatible with formation of the unusually large 9-membered chelate rings, although with an $\mathrm{O}-\mathrm{U}-\mathrm{O}$ bond angle of $88.25(14)^{\circ}$, considerably larger, for example, than that in 7 -membered 
rings ranging typically from 69 to $73^{\circ}$ found in complexes of cis- and trans-1,2cyclohexanedicarboxylates ${ }^{17}$ and possibly being one reason why the $\mathrm{U}^{\mathrm{VI}}$ centre has only five equatorial donor atoms when chelated in mode 2 . The dihedral angle between the two aromatic rings, denoted $\alpha$, and those between the $-\mathrm{COO}^{-}$groups and the attached aromatic ring, denoted $\beta_{1}$ and $\beta_{2}$, represented in Scheme 1, are important parameters of the dip ${ }^{2-}$ ligand. In $\mathbf{1}, \alpha$ is

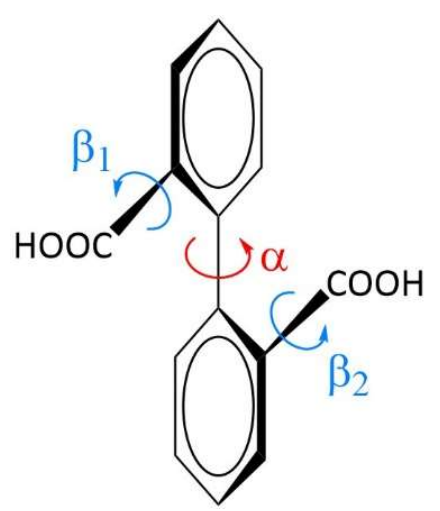

Scheme 1 Dihedral angles defining the geometry of $\mathrm{H}_{2}$ dip and its mono- and dianionic forms.

$64.03(16)^{\circ}$, a value smaller than those of $72.1(4)-90.0(3)^{\circ}$ found in uranyl ion complexes with 1,1'-diphenyl-2,2',6,6'-tetracarboxylate, ${ }^{13}$ and $\beta_{1}$ and $\beta_{2}$ are 57.1(5) and 47.9(6) ${ }^{\circ}$. The coordination polymer formed is monoperiodic (denoted 1D for convenience) and directed along [010]. The uranyl cations are arranged in groups of two related by inversion and with coordination polyhedra sharing the $\mathrm{O} 4-\mathrm{O} 4^{\mathrm{i}}$ edge. Viewed down the chain axis, the assembly has a bow tie-shaped section, with the aromatic rings protruding on both sides. The chains are arranged into layers parallel to (100), with possible interlayer parallel-displaced $\pi$-stacking interactions [centroid $\cdots$ centroid distance 4.251(4) $\AA$, dihedral angle $0^{\circ}$, slippage $2.28 \AA$ ]. However, as usual in such uranyl carboxylate complexes, examination of the Hirshfeld surface (HS), ${ }^{26}$ calculated using CrystalExplorer (Version 3.1) ${ }^{27}$ reveals that the most prominent interactions are of the $\mathrm{CH} \cdots \mathrm{O}$ hydrogen bonding type $\mathrm{e}^{28,29}$ and involve oxo and carboxylato groups [shortest $\mathrm{H} \cdots \mathrm{O}$ distance $2.57 \AA$ ]. The Kitaigorodski packing index (KPI, calculated with PLATON $^{30}$ ) of 0.66 indicates a compact packing with no solvent-accessible free spaces. 
The two complexes $\left[\mathrm{UO}_{2}(\operatorname{dip})(\right.$ bipy)$](2)$ and $\left[\mathrm{UO}_{2}(\operatorname{dip})(\right.$ phen) $)$ (3) crystallize in the same space group and with close unit cell parameters, and they will be described together. In both cases, the unique uranium atom is chelated in mode 1 by two carboxylate groups and the bipy or phen molecule, its environment being hexagonal bipyramidal [U-O(oxido) 1.756(3)-

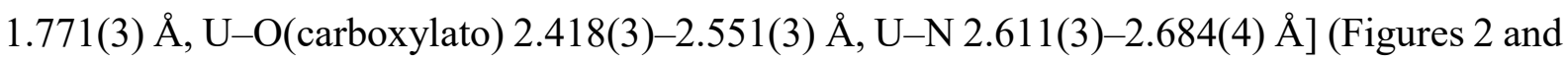

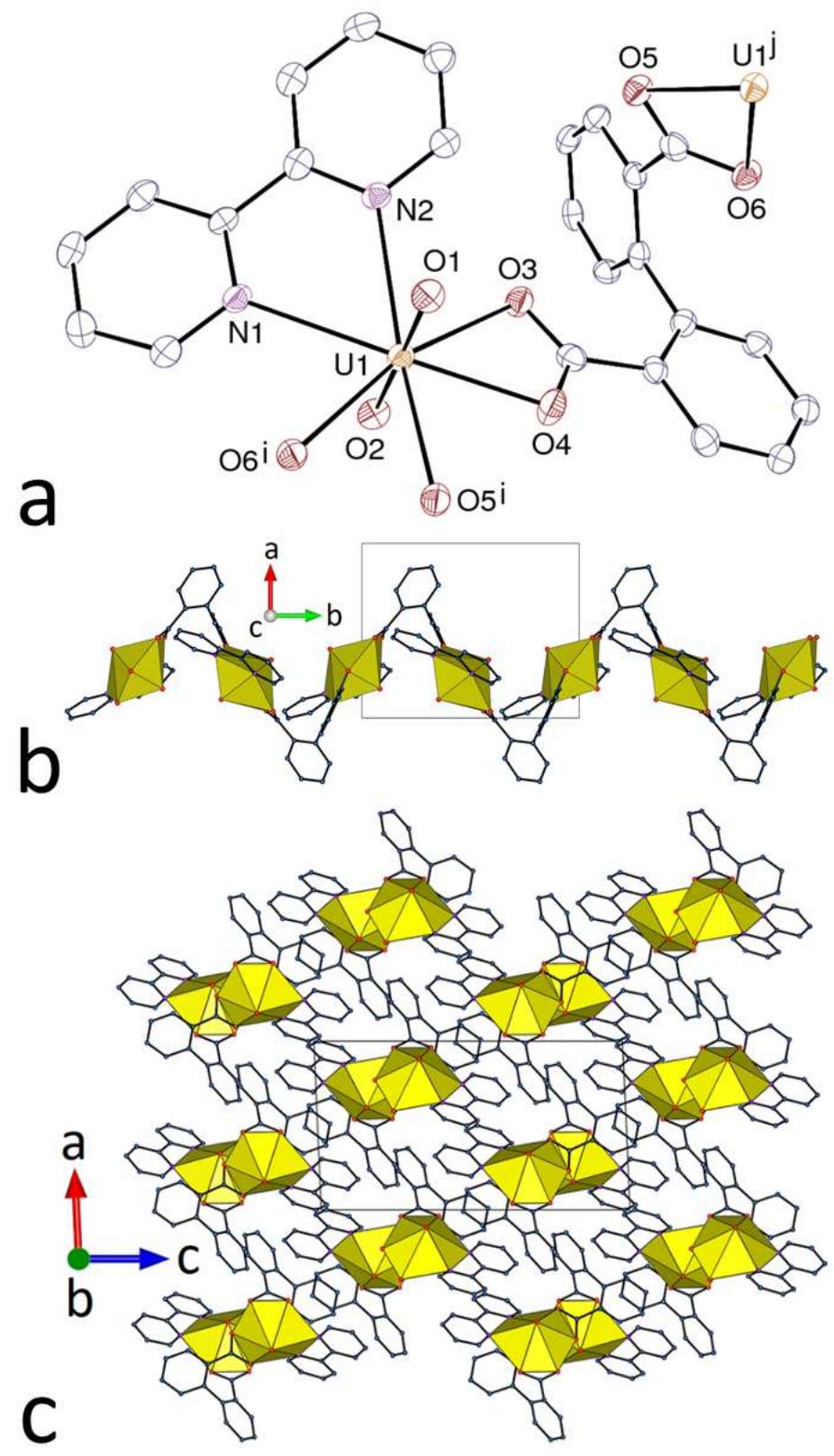

Fig. 2 (a) View of compound 2. Displacement ellipsoids are drawn at the 50\% probability level, and hydrogen atoms are omitted. Symmetry codes: $\mathrm{i}=3 / 2-x, y-1 / 2,1 / 2-z ; \mathrm{j}=3 / 2-x, y+1 / 2,1 / 2-z$. (b) View of the $1 \mathrm{D}$ polymer with uranium coordination polyhedra colored yellow. (c) Packing with the chains viewed end-on. 


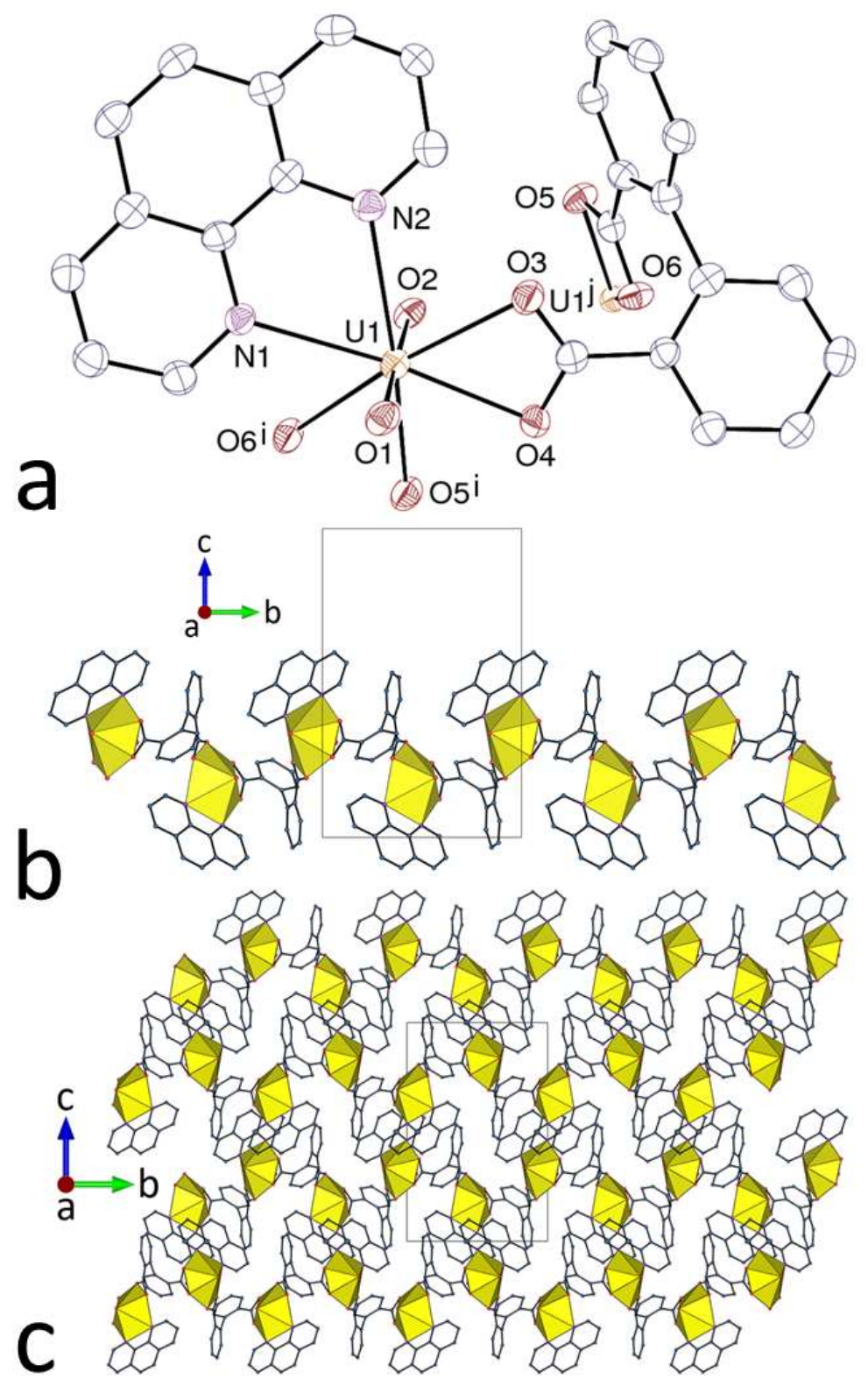

Fig. 3 (a) View of compound 3. Displacement ellipsoids are drawn at the 50\% probability level, and hydrogen atoms are omitted. Symmetry codes: $\mathrm{i}=1 / 2-x, y-1 / 2,1 / 2-z ; \mathrm{j}=1 / 2-x, y+1 / 2,1 / 2-z$. (b) View of the $1 \mathrm{D}$ polymer with uranium coordination polyhedra colored yellow. (c) Packing with the chains viewed edge-on.

3 ), and the dip ${ }^{2-}$ ligands are now apparently unable to form 9-membered (mode 2) chelate rings. As usual in uranyl ion complexes including a chelating bipy or phen molecule and two chelating carboxylates, the $N$-donor ligand is tilted with respect to the mean plane defined by uranium and the four carboxylate donors, ${ }^{31-33}$ the latter having a root mean square (rms) deviation of $0.09 \AA$ in both compounds. The dihedral angle between bipy or phen and this mean plane is 
$28.36(10)^{\circ}$ in $\mathbf{2}$ and $24.44(13)^{\circ}$ in $\mathbf{3}$, these values being in the usual range, with bipy being generally more tilted than phen. ${ }^{31}$ The $\alpha$ dihedral angles are $73.50(13)^{\circ}$ in 2 and $72.09(16)^{\circ}$ in 3 , and in both cases one $-\mathrm{COO}^{-}$group is nearly coplanar with the aromatic ring $[\beta$ dihedral angles $3.7(4)$ and $5.9(3)^{\circ}$ ] while the other is more tilted [39.5(3) and 34.6(4) ${ }^{\circ}$. A zigzag 1D coordination polymer running along [010] is formed in both compounds, with the aromatic groups pointing outward (views with different orientations are shown in Figs. 2 and 3). These chains are held together by multiple weak interactions, among which are parallel-displaced $\pi$ -

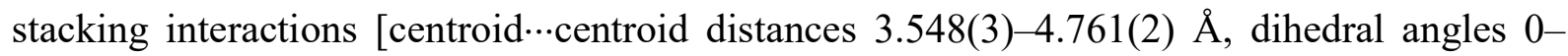
28.7(2) $)^{\circ}, \mathrm{CH} \cdots \pi$ interactions $\left[\mathrm{H} \cdots\right.$ centroid distances $2.58-2.82 \AA, \mathrm{C}-\mathrm{H} \cdots \pi$ angles $\left.138-168^{\circ}\right]$, and $\mathrm{CH} \cdots \mathrm{O}$ hydrogen bonds $\left[\mathrm{H} \cdots \mathrm{O}\right.$ distances $2.14-2.56 \AA, \mathrm{C}-\mathrm{H} \cdots \mathrm{O}$ angles $\left.111-146^{\circ}\right]$. These interactions result in compact packings, with KPIs of 0.73 in $\mathbf{2}$ and 0.71 in 3.

The complex $\left[\mathrm{H}_{2} \mathrm{NMe}_{2}\right]_{2}\left[\left(\mathrm{UO}_{2}\right)_{2}(\mathrm{dip})_{3}\right]$ (4) contains two independent uranyl cations, both chelated in mode 1 by three carboxylate groups [U-O(oxido) 1.760(3)-1.771(3) $\AA$, U$\mathrm{O}$ (carboxylato) 2.432(3)-2.511(3) A] from three independent ligands (Fig. 4). The availability of a sufficient number of donor atoms (here, all carboxylate oxygen donors, in contrast to $\mathbf{2}$ and 3 with two nitrogen in place of two oxygen donors) to form tris(mode 1) uranyl species appears again to exclude the occurrence of mode 2 chelation. The $\alpha$ dihedral angles are smaller than in 1-3 and the complexes of the tetracarboxylate analogue, at 61.82(13), 49.83(12) and $48.04(14)^{\circ}$. The $-\mathrm{COO}^{-}$groups are much less rotated in the ligand containing O5-O8 $[\beta$ dihedral angles $16.6(5)$ and $\left.17.4(4)^{\circ}\right]$ than in the other two $\left[41.7(3)-63.9(3)^{\circ}\right]$. The coordination polymer formed is $1 \mathrm{D}$ and parallel to [110], and it has a ladder-like shape, with two lateral rows connected by central ligands which are those less distorted from planarity. The $\mathrm{H}_{2} \mathrm{NMe}_{2}{ }^{+}$ cations are located within the chains and form simple or bifurcated hydrogen bonds with

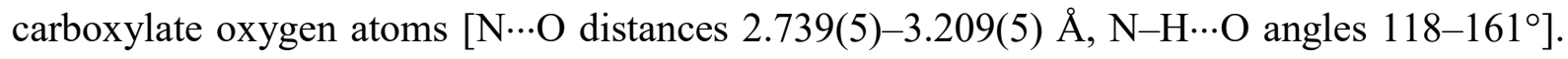
In particular, they connect the two carboxylate groups of each lateral ligand through formation 


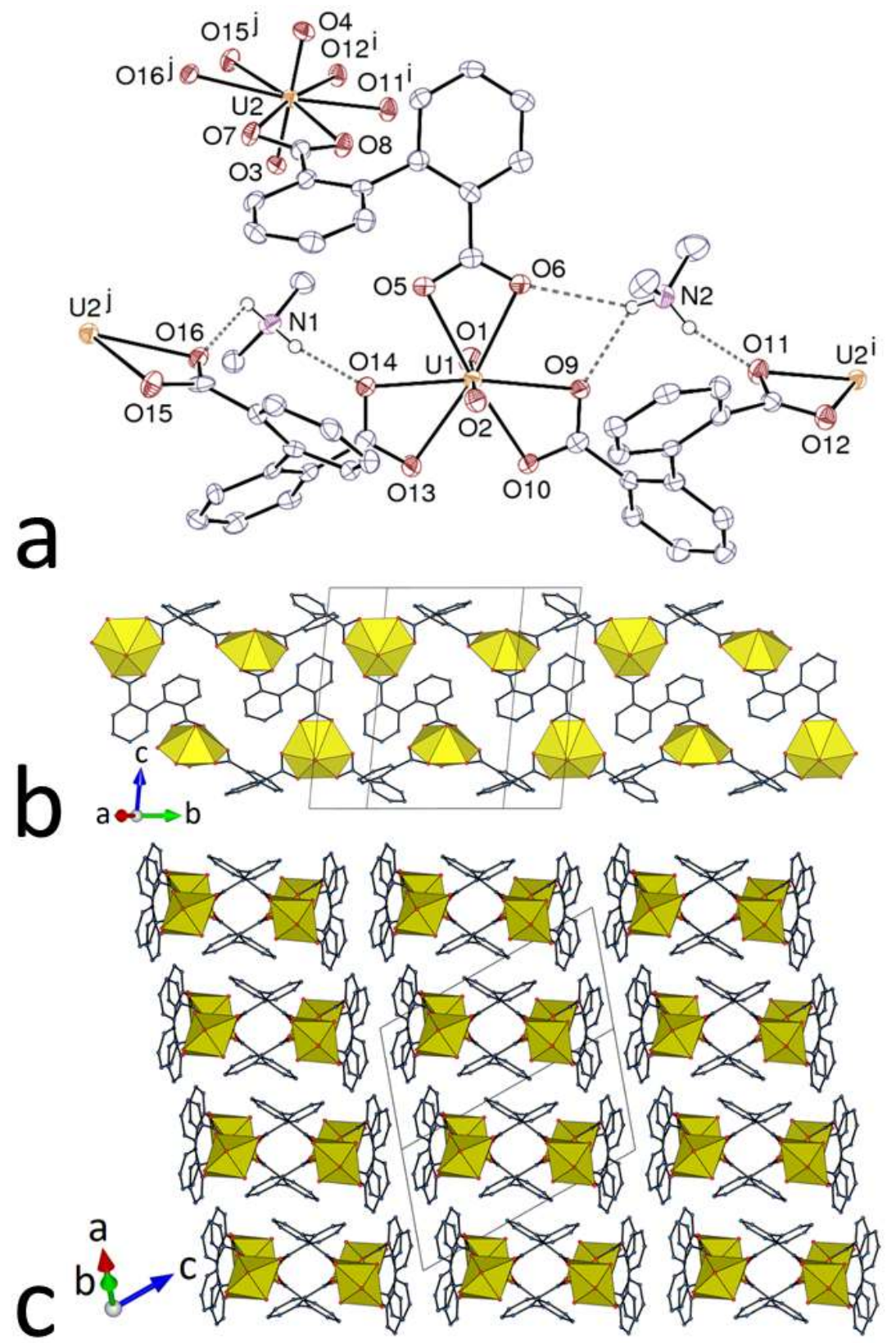

Fig. 4 (a) View of compound 4. Displacement ellipsoids are drawn at the 50\% probability level. Carbon-bound hydrogen atoms are omitted and the hydrogen bonds are shown as dashed lines. Symmetry codes: $\mathrm{i}=2-x, 1-y$, $1-z ; \mathrm{j}=1-x, 2-y, 1-z$. (b) View of the 1D polymer with uranium coordination polyhedra colored yellow. (c) Packing with the chains viewed end-on.

of rings with the graph set descriptor ${ }^{34,35} R_{2}^{2}(11)$, the bifurcated bond forming a smaller $R_{1}^{2}(4)$ ring. The lateral ligands of adjacent chains face one another through their aromatic rings and they are thus involved in possible parallel-displaced $\pi$-stacking interactions [centroid $\cdots$ centroid 
distances 3.876(3) and 3.885(3) $\AA$, dihedral angles $12.9(2)$ and $7.2(2)^{\circ}$, slippage 0.69 and 1.51 $\AA]$ ]. $\mathrm{CH} \cdots \pi$ interactions [H$\cdots$ centroid distances 2.52 and $2.77 \AA, \mathrm{C}-\mathrm{H} \cdots \pi$ angles 142 and $\left.125^{\circ}\right]$, and one $\mathrm{CH} \cdots \mathrm{O}$ hydrogen bond $\left[\mathrm{H} \cdots \mathrm{O}\right.$ distance $2.52 \AA, \mathrm{C}-\mathrm{H} \cdots \mathrm{O}$ angle $\left.118^{\circ}\right]$ may also contribute to the cohesion of the packing (KPI 0.69).

Complex 5, $\left[\left(\mathrm{UO}_{2}\right)_{2} \mathrm{Ag}_{2}(\mathrm{dip})_{3}\left(\mathrm{H}_{2} \mathrm{O}\right)\left(\mathrm{CH}_{3} \mathrm{CN}\right)\right]$, crystallizes in the same space group as 4 and with close unit cell parameters, and it can be considered to be isomorphous with it. The arrangement, with ladder-like chains built around tris-chelated uranyl cations [U-O(oxido)

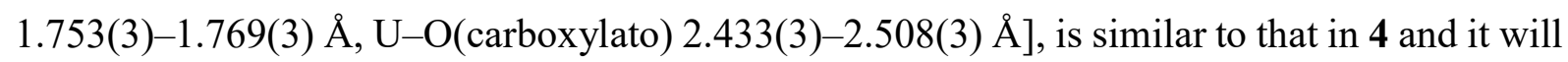
not be further described (Fig. 5). The $\alpha$ dihedral angles in each ligand are 74.11(13), 48.41(12) and $54.81(15)^{\circ}$, and, as in $\mathbf{4}$, the $-\mathrm{COO}^{-}$groups are much less rotated in the ligand containing O5-O8 $\left[\beta\right.$ dihedral angles $27.0(4)$ and $\left.22.5(5)^{\circ}\right]$ than in the other two $\left[40.1(3)-65.9(3)^{\circ}\right]$. The two $\mathrm{H}_{2} \mathrm{NMe}_{2}{ }^{+}$cations are replaced by one $\mathrm{Ag}\left(\mathrm{H}_{2} \mathrm{O}\right)^{+}$and one $\mathrm{Ag}\left(\mathrm{CH}_{3} \mathrm{CN}\right)^{+}$group, the metal atom in the latter being disordered (see Experimental). The silver(I) cations are bound to two carboxylate oxygen donors from each lateral ligand (those involved in hydrogen bonding in 4), with Ag-O bond lengths in the range of 2.244(13)-2.477(3) $\AA$, which matches the average value for such bonds in structures reported in the Cambridge Structural Database (CSD, version $5.40),{ }^{36,37} 2.38(15) \AA$. Short Ag-C contacts in the range of 2.479(4)-2.714(4) $\AA$ indicate interactions between the silver(I) cations and the aromatic rings, the average value for such bonds from the CSD being 2.50(20) $\AA$. The 9-membered (mode 2) chelate rings on Ag ${ }^{\mathrm{I}}$ involve $\mathrm{O}-\mathrm{Ag}-\mathrm{O}$ bond angles $\left[110.25(12)-122.63(10)^{\circ}\right]$ much larger than the $\mathrm{O}-\mathrm{U}-\mathrm{O}$ bond angle in complex 1 (see above), reflecting a certain degree of flexibility of $\mathrm{dpa}^{2-}$ as a chelate. The silver(I) cations have no direct role in the building of the coordination polymer, but are simply present as charge-balancing decorating groups which exploit the otherwise unused coordinating capacity of the uranyl-carboxylate polymer, in particular the $\pi$-donor property of the aromatic rings. It is notable that, in the same manner as $\mathrm{K}^{+}$and $\mathrm{NH}_{4}{ }^{+}$cations have somewhat similar 
properties, ${ }^{38} \mathrm{Ag}^{+}$appears to be here a perfect substitute for $\mathrm{H}_{2} \mathrm{NMe}_{2}{ }^{+}$, but this may be an exceptional case. Weak interactions in the packing (KPI 0.70) are analogous to those in 4 and will not be detailed further.

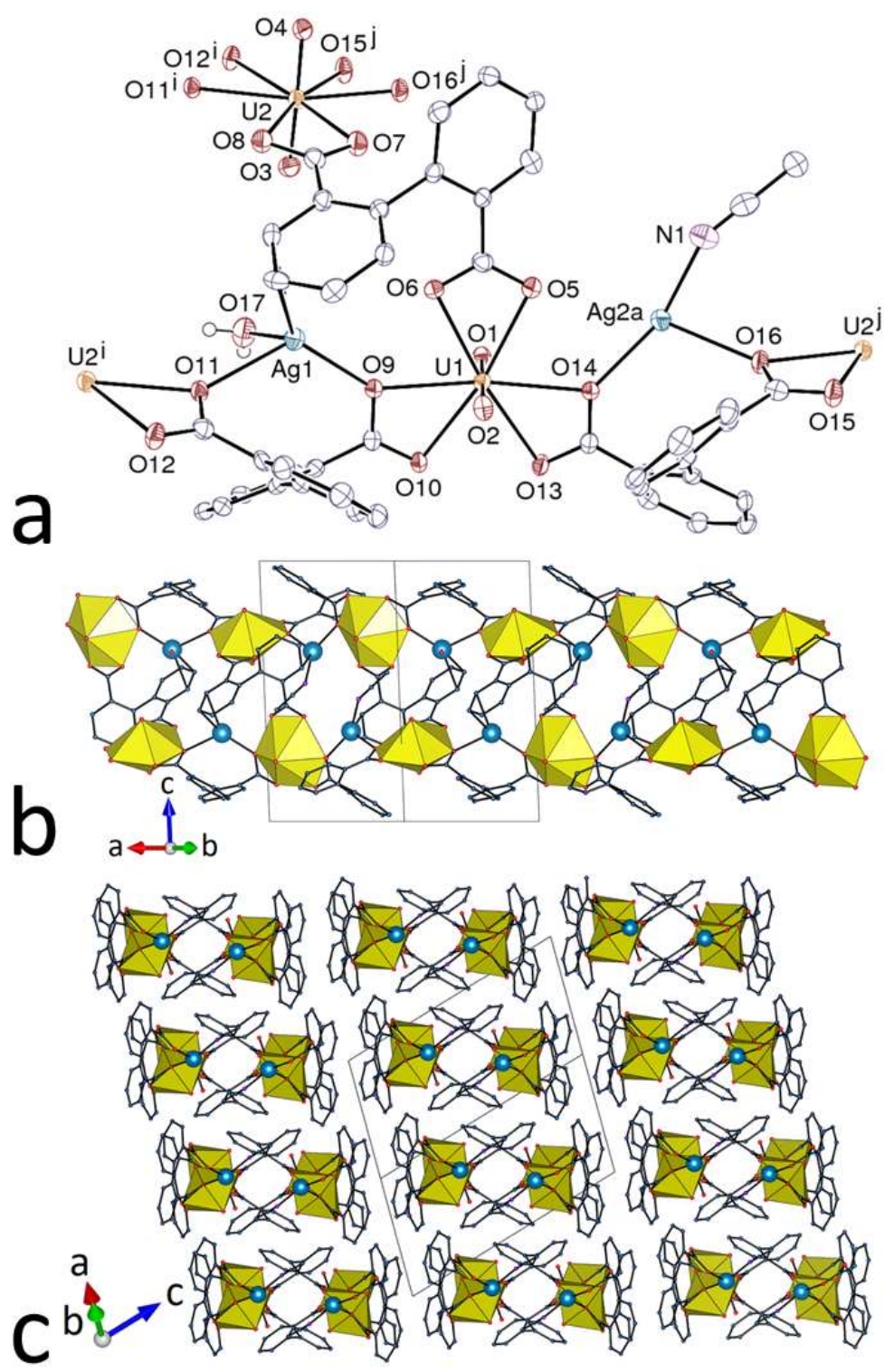

Fig. 5 (a) View of compound 5. Displacement ellipsoids are drawn at the 50\% probability level, and carbon-bound hydrogen atoms are omitted. Symmetry codes: $\mathrm{i}=1-x,-y, 1-z ; \mathrm{j}=-x, 1-y, 1-z$. (b) View of the 1D polymer with uranium coordination polyhedra colored yellow and silver(I) cations shown as blue spheres. (c) Packing with the chains viewed end-on. Only one position of the disordered silver(I) cation is represented in all views.

We have shown recently that complexes of d-block metal cations with the azamacrocycles cyclam or $R, S-\mathrm{Me}_{6}$ cyclam can be useful as counterions or building blocks 
(depending on whether the metal cation is additionally bound or not to carboxylate groups) in the synthesis of uranyl coordination polymers, ${ }^{17,18}$ and the four last complexes in this series involve such species. The complex $\left[\mathrm{Ni}\left(R, S\right.\right.$-Me ${ }_{6}$ cyclam $\left.)\left(\mathrm{H}_{2} \mathrm{O}\right)_{2}\right]\left[\mathrm{UO}_{2}(\operatorname{dip})_{2}\right]$ (6) has an asymmetric unit containing a unique uranium atom located on an inversion centre and chelated in mode 2 by two dip ${ }^{2-}$ ligands, its coordination environment being thus square bipyramidal (Fig. 6), a geometry less common than the pentagonal and hexagonal bipyramidal ones, but

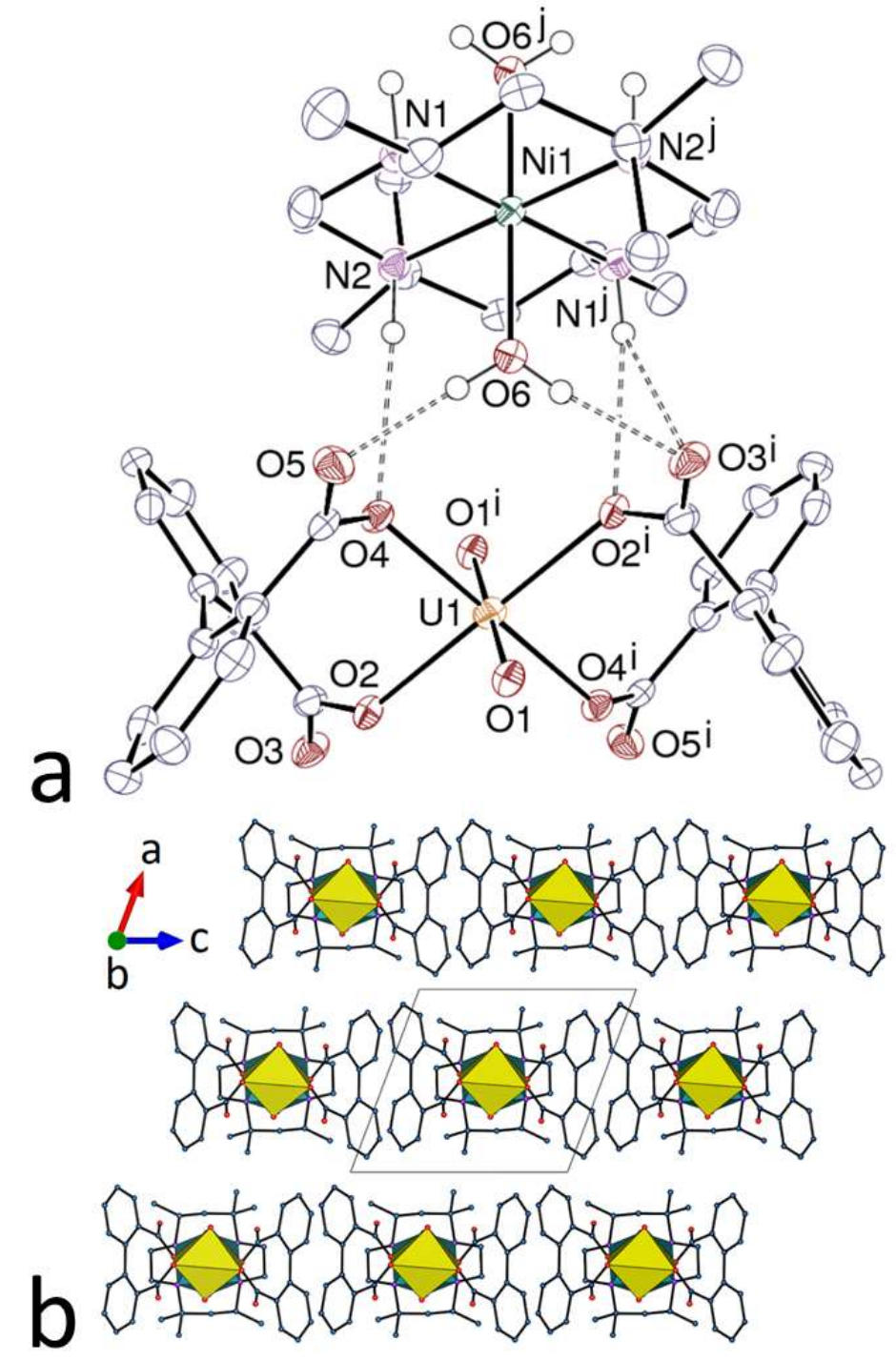

Fig. 6 (a) View of compound 6. Displacement ellipsoids are drawn at the 50\% probability level. Carbon-bound hydrogen atoms are omitted and the hydrogen bonds are shown as dashed lines. Symmetry codes: $\mathrm{i}=1-x, 1-y$, $1-z ; \mathrm{j}=1-x,-y, 1-z$. (b) View of the packing with uranium coordination polyhedra colored yellow and those of nickel(II) green. 
found nevertheless in more than 50 uranyl carboxylate complexes reported in the CSD. The bond lengths in the equatorial plane are particularly small due to the reduced coordination number [U-O(oxido) 1.772(2) A, U-O(carboxylato) 2.301(3) and 2.303(2) $\AA$, to be compared to the average value of 2.32(6) $\AA$ from the CSD]. The ligand chelates uranium as a mode 2 species, with each carboxylate group being bound in the simple $\kappa^{1}-O$ monodentate mode, so that there is no polymer formation and the uranyl complex is zero-periodic. The $\alpha, \beta_{1}$ and $\beta_{2}$ dihedral angles are $74.31(12)^{\circ}, 36.8(6)$ and $34.8(3)^{\circ}$ and the $\mathrm{O}-\mathrm{U}-\mathrm{O}$ bond angle in the 9membered chelate rings is $87.77(9)^{\circ}$, very similar to that in complex $\mathbf{1}$. The centrosymmetric counterion, with the nickel(II) centre bound to the four nitrogen donors and two axial water molecules [Ni-N 2.065(3) and 2.102(3) $\AA, \mathrm{Ni}-\mathrm{O} 2.149(3) \AA]$, is hydrogen bonded to two anions through both the water molecules which are linked to two uncoordinated oxygen atoms each [O $\cdots \mathrm{O}$ distances 2.808(3) and 2.728(4) $\AA, \mathrm{O}-\mathrm{H} \cdots \mathrm{O}$ angles $172(5)$ and $\left.178(4)^{\circ}\right]$, and the $\mathrm{NH}$ groups which form simple or bifurcated bonds with both coordinated and uncoordinated oxygen atoms $\left[\mathrm{N} \cdots \mathrm{O}\right.$ distances 3.287(4)-3.476(4) $\AA$, N-H $\cdots \mathrm{O}$ angles $\left.145(3)-166(3)^{\circ}\right]$. The water molecule thus form a hydrogen bonding ring with the graph set descriptor $R_{2}^{2}(10)$, the $\mathrm{N} 1 \mathrm{H}$ group forms a $R_{1}^{2}(4)$ ring, and both $\mathrm{N} 1 \mathrm{H}$ and $\mathrm{N} 2 \mathrm{H}$ groups form a $R_{2}^{2}(8)$ shortest ring. These hydrogen bonds generate chains directed along [010] which, when viewed down the chain axis, display a shape analogous to that of the $1 \mathrm{D}$ coordination polymer in complex $\mathbf{1}$. Although the packing is compact (KPI 0.70), the aromatic rings are farther apart than in the other complexes and no $\pi$-stacking or $\mathrm{CH} \cdots \pi$ interaction is present, but $\mathrm{CH} \cdots \mathrm{O}$ hydrogen bonds further link cations and anions within the chains $\left[\mathrm{H} \cdots \mathrm{O}\right.$ distances $2.50-2.58 \AA, \mathrm{C}-\mathrm{H} \cdots \mathrm{O}$ angles $\left.143-154^{\circ}\right]$. Replacing $R, S-\mathrm{Me}_{6}$ cyclam by cyclam, and also DMF by acetonitrile as a co-solvent, resulted in the formation of the complex $\left[\left(\mathrm{UO}_{2}\right)_{2}(\mathrm{dip})_{2}(\mathrm{Hdip})_{2} \mathrm{Ni}(\right.$ cyclam $\left.)\right] \cdot 2 \mathrm{H}_{2} \mathrm{O} \cdot 2 \mathrm{CH}_{3} \mathrm{CN}(7)$, in which half the ligands are in the monoprotonated Hdip ${ }^{-}$form (Fig. 7). The unique uranium 

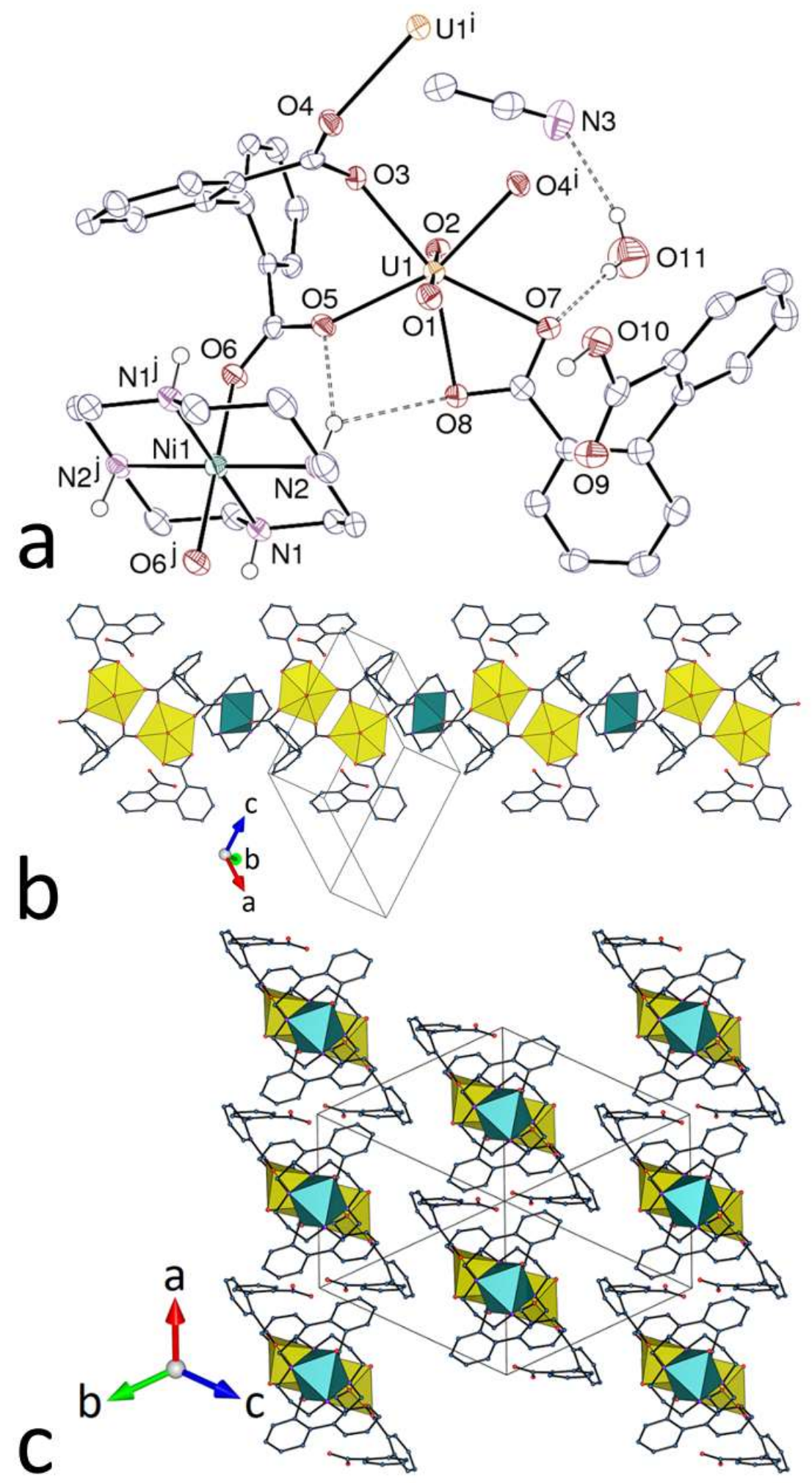

Fig. 7 (a) View of compound 7. Displacement ellipsoids are drawn at the $50 \%$ probability level. Carbon-bound hydrogen atoms are omitted and the hydrogen bonds are shown as dashed lines. Symmetry codes: $\mathrm{i}=2-x, 1-y$, $1-z ; \mathrm{j}=1-x,-y,-z$. (b) View of the 1D polymer with uranium coordination polyhedra colored yellow and those of nickel(II) green. (c) Packing with the chains viewed end-on and hydrogen bonded layers vertical. 
atom is chelated in mode 1 by the carboxylate group of $\mathrm{Hdip}^{-}$, chelated in mode 2 by $\operatorname{dip}^{2-}$, and bound to one more carboxylate donor from another diprotonated ligand, the coordination environment being pentagonal bipyramidal [U-O(oxido) 1.765(2) and 1.767(2) $\AA$, U$\mathrm{O}$ (carboxylato) $2.441(2)$ and 2.466(2) $\AA$ for the chelating group, and 2.331(2)-2.360(3) $\AA$ for the other groups]. The $\alpha$ dihedral angles are $82.89(12)$ and $57.06(11)^{\circ}$ in the $\operatorname{dip}^{2-}$ and Hdip ${ }^{-}$ ligands, respectively, and only one carboxylate group in the former ligand is strongly tilted with respect to the aromatic ring $\left[\beta\right.$ dihedral angle $74.55(17)^{\circ}, 17.5(4)-23.5(3)^{\circ}$ for the other groups]. The nickel(II) cation, located on an inversion centre, is bound to the four nitrogen donors of the macrocycle and two axial carboxylate oxygen atoms $[\mathrm{Ni}-\mathrm{N} 2.059(3)$ and 2.076(3) $\AA$, Ni-O 2.176(2) $\AA$ ]. In contrast to the case of complex $6, \mathrm{Ni}^{\mathrm{II}}$ is thus part of the coordination polymer, which is $1 \mathrm{D}$ and runs along the [111] direction. The additional coordination interactions (rather than just hydrogen bonding) of the carboxylate groups involved in mode 2 uranium chelation are associated with a significant decrease in the $\mathrm{O}-\mathrm{U}-\mathrm{O}$ bond angle $\left[77.22(8)^{\circ}\right]$ relative to the values seen in complexes $\mathbf{1}$ and $\mathbf{6}$. The $\operatorname{dip}^{2-}$ ligand is bound to two uranium and one nickel centres and its two carboxylate groups adopt the syn/anti $\mu_{2}-\kappa^{1} O: \kappa^{1} O^{\prime}$ coordination mode (with one uranium atom common to both), while the carboxylate group of $\mathrm{Hdip}^{-}$is $\kappa^{2} O, O^{\prime}$-chelating, the carboxylic acid group being uncoordinated. The polymeric chain displays an alternation of centrosymmetric uranyl dimers and centrosymmetric nickel(II) complexes. The carboxylic groups are directed outward in such a manner that layers parallel to (011) are assembled through reciprocal hydrogen bonding of the $-\mathrm{COOH}$ groups with their image by inversion $[\mathrm{O} \cdots \mathrm{O}$

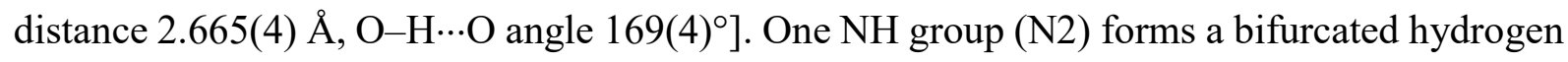
bond with two carboxylate oxygen atoms bound to the same uranium atom $\left[R_{1}^{2}(4), \mathrm{N} \cdots \mathrm{O}\right.$ 2.860(4) and 3.239(4) $\AA, \mathrm{N}-\mathrm{H} \cdots \mathrm{O} 154(3)$ and $\left.129(3)^{\circ}\right]$, while the other group (N1) may be involved in an intrachain $\mathrm{NH} \cdots \pi$ interaction with the aromatic ring corresponding to atoms $\mathrm{O} 3$ and $\mathrm{O} 4\left[\mathrm{H} \cdots\right.$ centroid distance $2.85(4) \AA, \mathrm{N}-\mathrm{H} \cdots$ centroid angle $\left.156(4)^{\circ}\right]$. The water molecule is 
hydrogen bonded to a carboxylate group and the acetonitrile solvent molecule, the KPI of 0.69 indicating that no free space is present. There is only one possible intrachain $\pi$-stacking

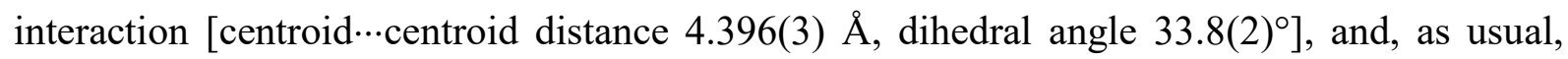
several $\mathrm{CH} \cdots \mathrm{O}$ hydrogen bonds involving oxo and carboxylato groups $[\mathrm{H} \cdots \mathrm{O}$ distances 2.50 $2.58 \AA, \mathrm{C}-\mathrm{H} \cdots \mathrm{O}$ angles $\left.112-153^{\circ}\right]$.

The two complexes $\left[\mathrm{Cu}\left(R, S-\mathrm{Me}_{6}\right.\right.$ cyclam $\left.)\right]\left[\mathrm{UO}_{2}(\operatorname{dip})\left(\mathrm{NO}_{3}\right)\right]_{2}(8)$ and $\left[\left(\mathrm{UO}_{2}\right)_{3}(\mathrm{dip})_{4} \mathrm{Cu}-\right.$ $\left(R, S\right.$ - $\mathrm{Me}_{6}$ cyclam $\left.)\left(\mathrm{H}_{2} \mathrm{O}\right)_{2}\right] \cdot 6 \mathrm{H}_{2} \mathrm{O}(9)$ were crystallized together from the same solution, and they are distinguishable by their colour, yellow for $\mathbf{8}$ and purple for $\mathbf{9}$. The unique uranium atom in $\mathbf{8}$ is chelated in mode 2 by one ligand, and bound to one more carboxylate oxygen donor from a second ligand and a chelating nitrate ion [U-O(oxido) 1.742(4) and 1.750(4) $\AA$, U$\mathrm{O}$ (carboxylato) 2.293(4)-2.372(4) $\AA, \mathrm{U}-\mathrm{O}$ (nitrato) $2.532(5)$ and $2.551(4) \AA]$, the mode 2 chelation $\mathrm{O}-\mathrm{U}-\mathrm{O}$ bond angle being $87.36(15)^{\circ}$ (Fig. 8). Discrete centrosymmetric, dinuclear uranyl dimers are formed, the terminal nitrate anion preventing polymerization. The $\alpha, \beta_{1}$ and $\beta_{2}$ dihedral angle are $72.5(2)^{\circ}, 39.3(4)$ and $48.3(6)^{\circ}$. The $\mathrm{Cu}^{\mathrm{II}}$ cation, located on an inversion centre, is bound to the four nitrogen atoms of the macrocycle, and has a square planar environment [Cu-N 2.019(5) and 2.037(5) $\AA$ ]. Hydrogen bonding of the NH groups to nitrate and uncoordinated carboxylate oxygen atoms [N..O distances 2.981(7) and 2.866(7) $\AA, \mathrm{N}-$ $\mathrm{H} \cdots \mathrm{O}$ angles $166(5)$ and $\left.151(5)^{\circ}\right]$ gives rise to the formation of chains directed along [10i] , and these chains are arranged into sheets parallel to (010), the packing of which leaves no free space (KPI 0.70). No parallel $\pi$-stacking interaction is present, and only one interlayer $\mathrm{CH} \cdots \pi$ interaction involving an aromatic proton may be found $[\mathrm{H} \cdots$ centroid distance $2.94 \AA, \mathrm{C}-$ H...centroid angle $\left.158^{\circ}\right]$. 


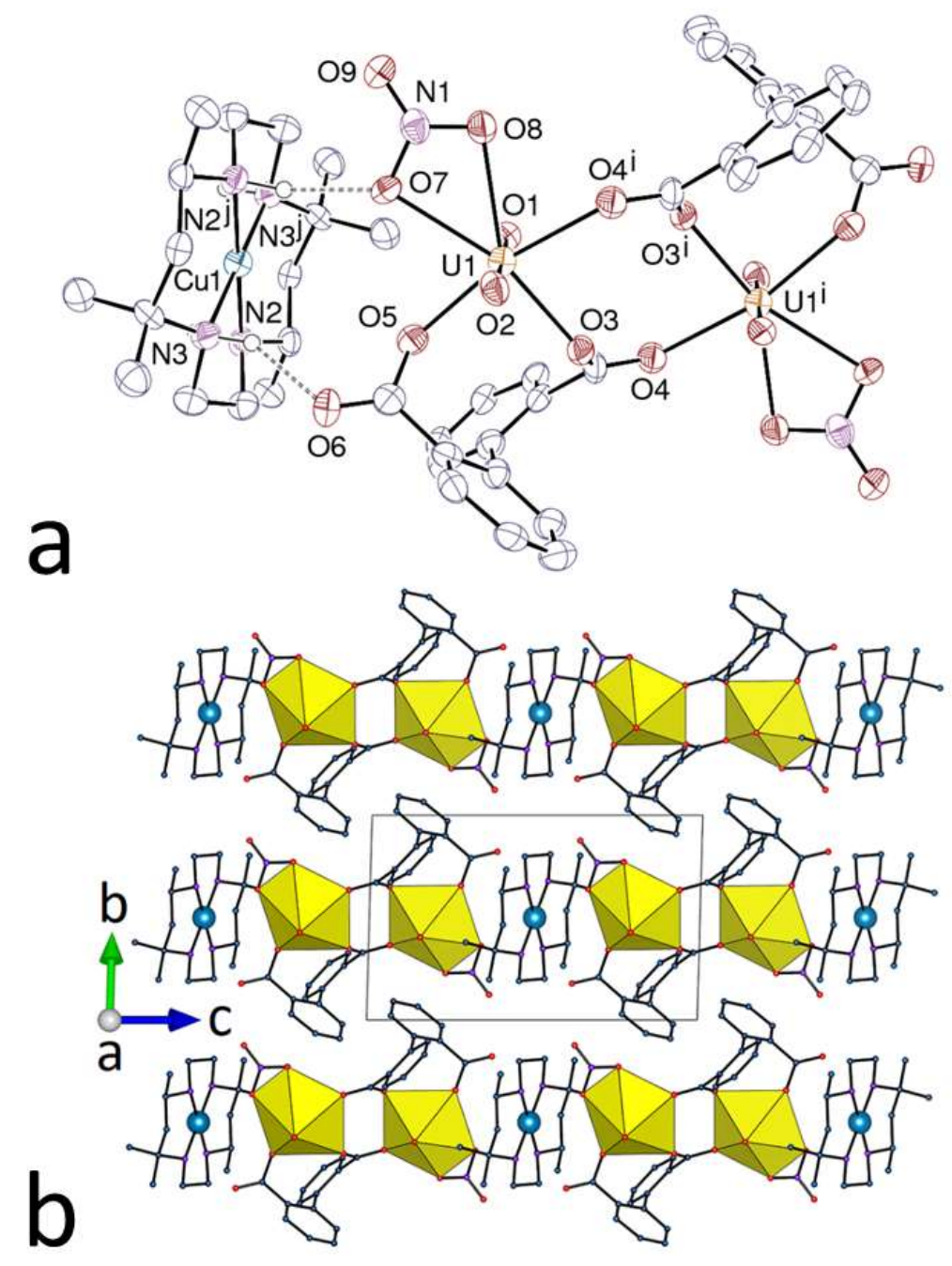

Fig. 8 (a) View of compound 8. Displacement ellipsoids are drawn at the $50 \%$ probability level. Carbon-bound hydrogen atoms are omitted and the hydrogen bonds are shown as dashed lines. Symmetry codes: $\mathrm{i}=-x, 1-y, 2$ $-z ; \mathrm{j}=1-x, 1-y, 1-z$. (b) View of the packing with uranium coordination polyhedra colored yellow and copper(II) cations shown as blue spheres.

While the presence of terminal nitrate and the absence of axial $\mathrm{Cu}^{\mathrm{II}}$ bonding in $\mathbf{8}$ only allowed for the formation of a zero-periodic complex, these limitations are removed in complex 9. As shown in Fig. 9, the two independent uranium atoms are in different environments. Atom $\mathrm{U} 1$ is chelated in mode 1 by one ligand, chelated in mode 2 by a second ligand, and bound to another carboxylate donor from a third, its environment being pentagonal bipyramidal, while atom $\mathrm{U} 2$, located on an inversion centre, is chelated in mode 1 by two ligands and bound to two water molecules [U-O(oxido) 1.756(4)-1.784(5) A, U-O(carboxylato) 2.430(5)-2.483(5) $\AA$ 


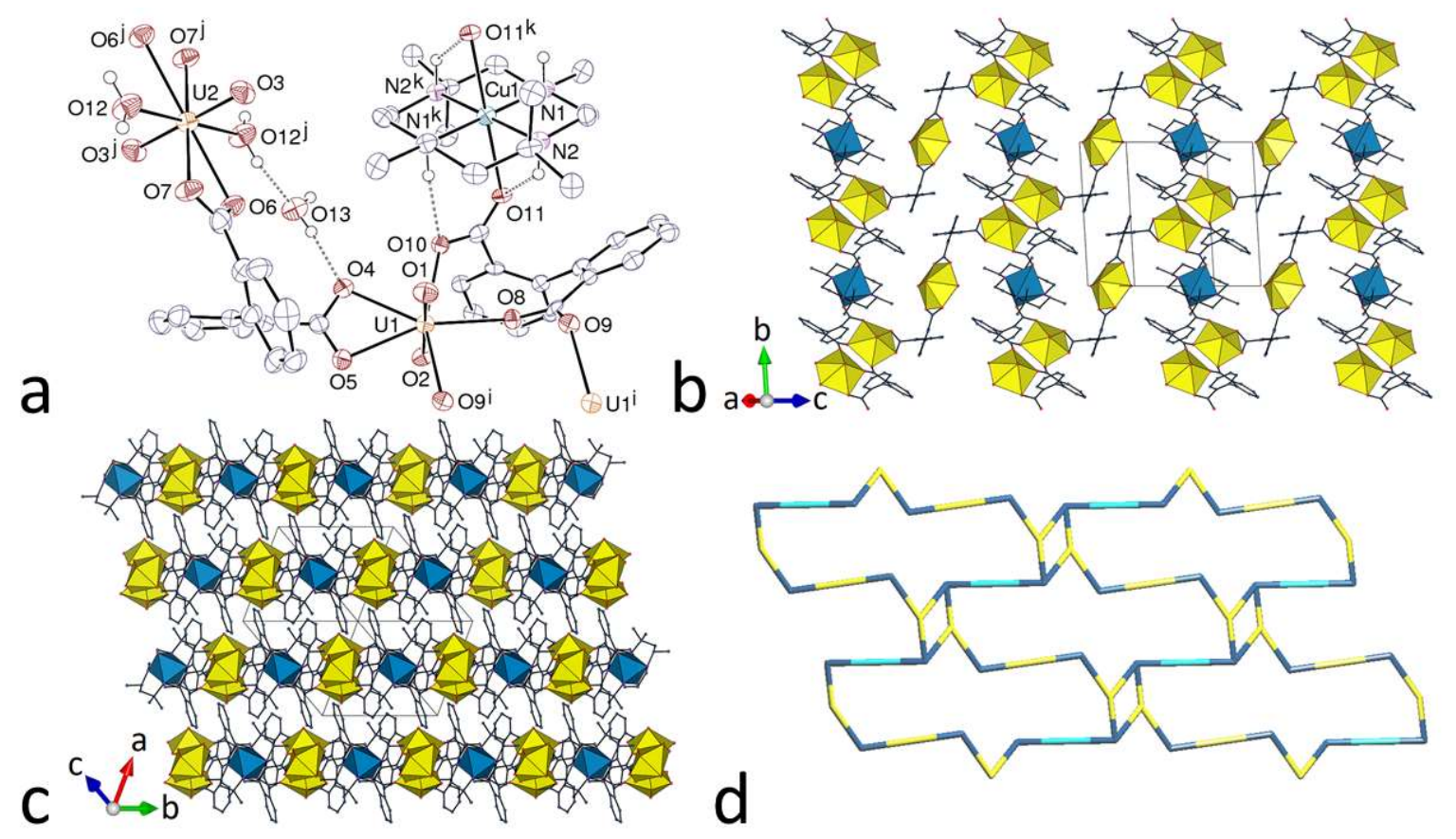

Fig. 9 (a) View of compound 9. Displacement ellipsoids are drawn at the 50\% probability level. Carbon-bound hydrogen atoms are omitted, and the hydrogen bonds are shown as dashed lines. Symmetry codes: $\mathrm{i}=-x, 1-y, 1$ $-z ; \mathrm{j}=1-x,-y,-z ; \mathrm{k}=-x,-y, 1-z$. (b) View of the 2D network with uranium coordination polyhedra colored yellow and those of copper(II) blue. (c) Packing with layers viewed edge-on. (d) Topology of the 2D network (uranium, yellow; copper, light blue; dicarboxylate ligand, dark blue; orientation rotated with respect to that in (b)).

for mode 1 chelating groups, and 2.318(4)-2.393(5) $\AA$ for the other groups, U-O(water) 2.471(5) $\AA$ ]. One ligand, containing atoms $\mathrm{O} 4-\mathrm{O} 7$, is thus bis- $\kappa^{2}-O, O^{\prime}$-chelating, and the other, containing $\mathrm{O} 8-\mathrm{O} 11$, is bis- $\mu_{2}-\kappa^{1} O: \kappa^{1} O^{\prime}$-bridging, with one metal atom common to both groups. Again, an apparent effect of differences in the additional interactions of the carboxylate groups forming mode 2 chelates is seen in that the relevant $\mathrm{O}-\mathrm{U}-\mathrm{O}$ bond angle is $74.80(15)^{\circ}$. The $\alpha$ dihedral angles are 65.0(3) and $65.85(16)^{\circ}$ in these two ligands, respectively, while the $\beta_{1}$ and $\beta_{2}$ angles are $67.0(3)$ and $38.8(5)^{\circ}$ in the first, and $9.6(9)$ and $50.8(5)^{\circ}$ in the second. The $\mathrm{Cu}^{\mathrm{II}}$ cation, located on an inversion centre, is bound to the four macrocyclic nitrogen atoms and two axial carboxylate groups $[\mathrm{Cu}-\mathrm{N} 2.020(6)$ and 2.043(5) $\AA, \mathrm{Cu}-\mathrm{O} 2.423(4) \AA]$, and it is thus in an axially elongated octahedral environment. The $\mathrm{NH}$ groups form hydrogen bonds with the 
two oxygen atoms of the carboxylate group bound to copper(II) $\left[R_{1}{ }^{1}(4)\right.$ and $R_{1}{ }^{1}(6)$ rings; $\mathrm{N} \cdots \mathrm{O}$ distances $2.911(7)$ and 3.092(7) $\AA, \mathrm{N}-\mathrm{H} \cdots \mathrm{O}$ angles $131(5)$ and $\left.173(5)^{\circ}\right]$, a pattern frequently observed which may promote axial coordination of the d-block metal cation. ${ }^{17,18}$ Atom U1 is involved in the formation of centrosymmetric dinuclear units analogous to those found in $\mathbf{8}$, but here bridging by $\mathrm{Cu}^{\mathrm{II}}$ gives chains parallel to [010], and further bridging of chains by U2 generates a diperiodic network parallel to (101). U2, Cu1, and the bis-chelating ligand are simple links, while U1 and the other ligand are trigonal nodes, and the net has the point symbol $\left\{4.8^{2}\right\}$ and the topological type fes (alternatively, if the U1-containing dimers are considered as single, fourfold nodes, the net has the sql topology). The fes topology is a rather common one, ${ }^{39}$ and, in particular, it has been found in several uranyl-containing species in which bridging carboxylate groups produce dinuclear subunits corresponding to the four-membered rings of the net. ${ }^{40-44}$ In some of these cases, the ligands involved are also chelating a single uranyl cation in the dimer through two coordination sites, either two carboxylate groups, ${ }^{42}$ as in $\mathbf{9}$, or one carboxylate and one sulfonate. ${ }^{40,44}$ Aromatic groups protrude on the two sides of the layers in 9, and the interdigitated packing (KPI 0.69) allows for two interlayer parallel-displaced $\pi$ -

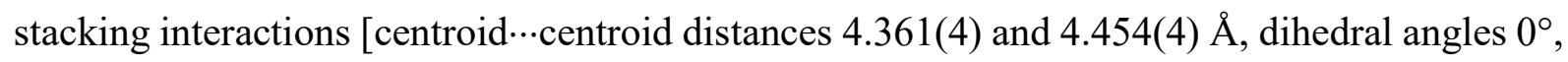
slippage 2.64 and $2.82 \AA]$, as well as three inter- and intralayer $\mathrm{CH} \cdots \pi$ interactions $[\mathrm{H} \cdots$ centroid distances 2.90-2.99 $\AA, \mathrm{C}-\mathrm{H} \cdots$ centroid angles $\left.143-155^{\circ}\right]$. $\mathrm{CH} \cdots \mathrm{O}$ hydrogen bonds are only intralayer and involve oxo and carboxylato groups $[\mathrm{H} \cdots \mathrm{O}$ distances 2.52 and $2.59 \AA$, $\mathrm{C}-\mathrm{H} \cdots \mathrm{O}$ angles 154 and $142^{\circ}$ ].

Although most complexes in the present series are monoperiodic, with two occurrences of zero-periodic compounds and one of a diperiodic network, the coordination mode of the ligand is somewhat varied, as shown in Scheme 2. The most common mode is bis- $\kappa^{2}-O, O^{\prime}-$ 


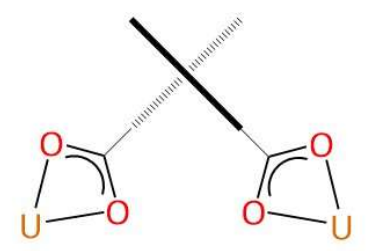

$2,3,4,5,9$
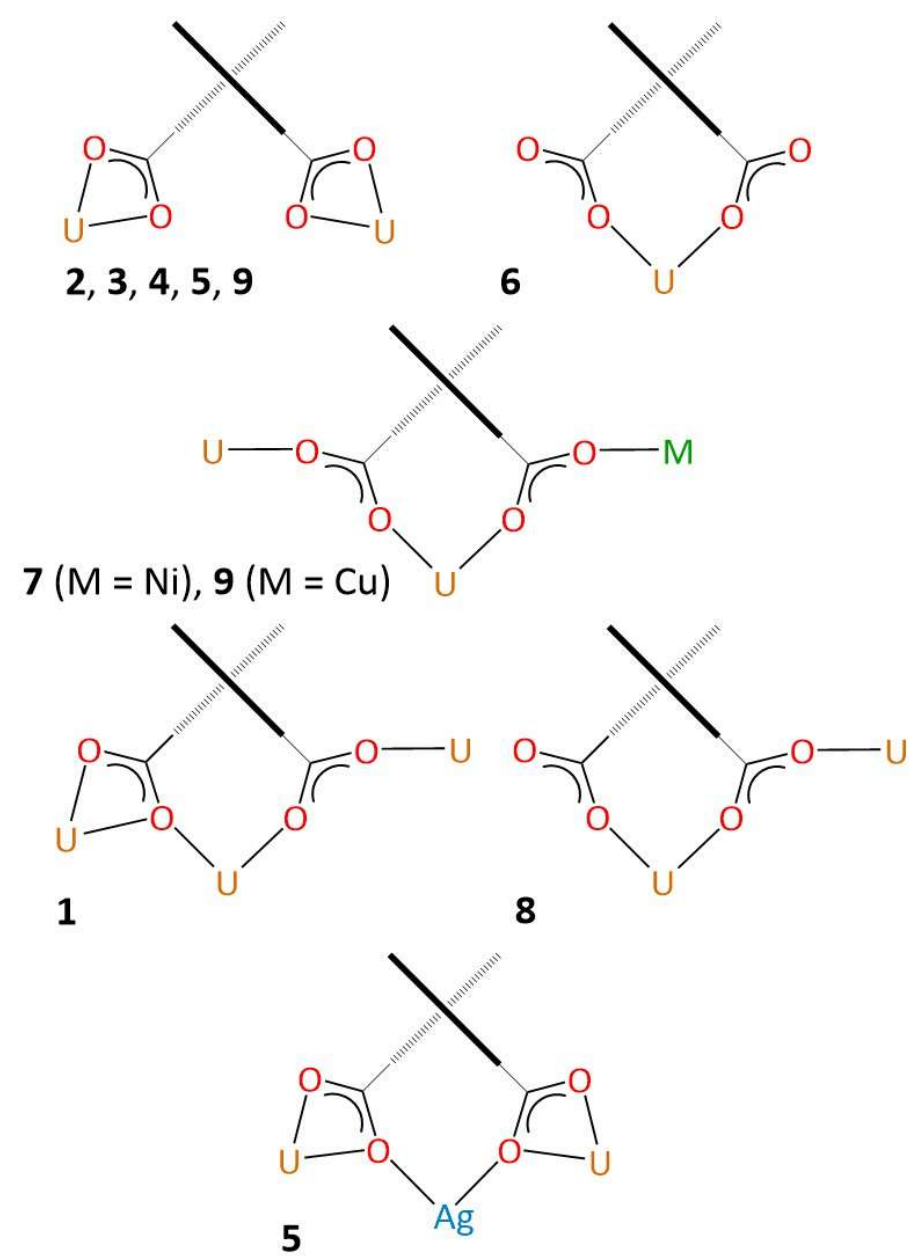

Scheme 2 Coordination mode of $\mathrm{dip}^{2-}$ in complexes 1-9. The ligand is viewed down the central bond, and the aromatic rings are represented orthogonal to one another.

chelating, found in $\mathbf{2}-\mathbf{5}$ and $\mathbf{9}$, with also, in $\mathbf{5}$, a related mode with an additional silver(I) cation chelated in mode 2; in these complexes, it is when silver(I) is present, or when $\mathrm{H}_{2} \mathrm{NMe}_{2}{ }^{+}$is hydrogen bonded to both carboxylate groups in complex $\mathbf{4}$ that the lowest $\alpha$ dihedral angles are observed $\left[48.04(14)-54.81(15)^{\circ}\right]$, the widest aperture being directed toward the cation, while the other ligands in the same complexes give values in the range of $61.82(13)-74.11(13)^{\circ}$. In these ligands with the lowest $\alpha$ values, the $\beta$ dihedral angles are larger than in the other ligands of the same complexes $\left[40.1(3)-65.9(3)^{\circ}\right.$ versus $\left.16.6(5)-27.0(4)^{\circ}\right]$, these differences in geometry being probably necessary for accommodation of the $\mathrm{Ag}^{+}$and $\mathrm{H}_{2} \mathrm{NMe}_{2}{ }^{+}$cations. Mode 2 chelation of uranyl, present in $\mathbf{1}$ and 6-9, has no similar effect since the $\alpha$ angles are in the 
range of $64.03(16)-82.89(12)^{\circ}$, while the $\beta$ angles vary within the large range of 9.6(9)$74.55(17)^{\circ}$; except in complex $\mathbf{6}$, this coordination mode is associated to diverse bridging or mode 1 chelation, by only one $(\mathbf{8})$ or the two carboxylate groups $(\mathbf{1}, \mathbf{7 , 9})$. In the more than 300 crystal structures containing coordinated or free, neutral, mono- or dianionic forms of $\mathrm{H}_{2} \mathrm{dip}$ reported in the CSD, the $\beta$ dihedral angles vary over all the possible range, from $\sim 0$ to $\sim 90^{\circ}$, while the $\alpha$ angle does not reach values below $\sim 38^{\circ}$. In the present instances, $\alpha$ varies from $48.04(14)^{\circ}$ for a bis- $\kappa^{2}-O, O^{\prime}$-chelating ligand in 4 to $82.89(12)^{\circ}$ for a ligand chelating in mode 2 and bis-bridging in 7, these values being thus in the usual range. In the homo- and heterometallic uranyl ion complexes of the related 1,1'-diphenyl-2,2',6,6'-tetracarboxylate, ${ }^{13}$ the $\alpha$ angles are overall larger $\left[72.1(4)-90.0(3)^{\circ}\right]$, the geometry being close to $D_{2 d}$ symmetry, and the $\beta$ angles vary over an even larger range $\left[3.0(9)-86.5(3)^{\circ}\right]$. It is notable that, curiously enough, the structural disorder frequently present in these uranyl tetracarboxylate complexes, in particular the rotational disorder of carboxylate groups, is altogether absent in the present dicarboxylate complexes. The coordination modes found in the tetracarboxylate complexes are a mixture of the same mode $1 /$ mode 2 chelation and bridging geometries present here, but the larger ligand denticity and more divergent nature result in overall higher periodicity, with diperiodic networks being dominant and one instance of a triperiodic framework. ${ }^{13}$ In the present dicarboxylate complexes and whatever the coordination mode, limitation of the connectivity to one side of the ligand limits the periodicity of the assemblies formed.

\section{Luminescence properties}

Emission spectra under excitation at $420 \mathrm{~nm}$ were recorded for complexes $\mathbf{3}-\mathbf{5}$ and $\mathbf{7}$ in the solid state (Fig. 10), the other complexes having been obtained in insufficient yield and purity, or as 


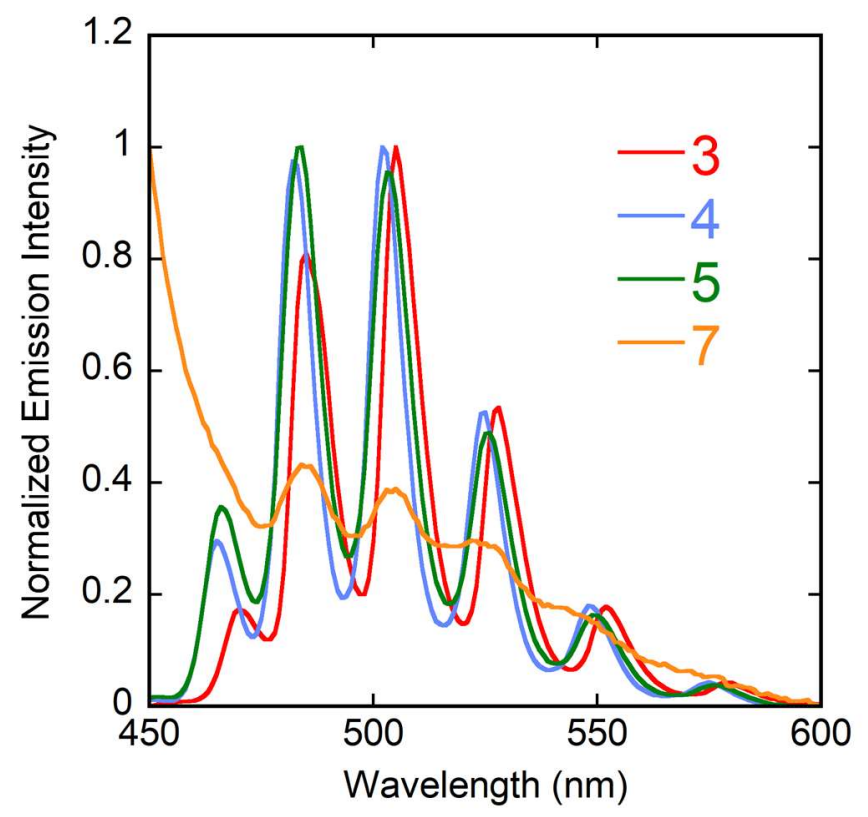

Fig. 10 Normalised emission spectra of compounds 3-5 and 7, recorded in the solid state at room temperature, under excitation at a wavelength of $420 \mathrm{~nm}$.

mixtures (8 and 9). The spectra of complexes 3-5 display the usual well-resolved series of peaks associated with the vibronic progression corresponding to the $S_{11} \rightarrow S_{00}$ and $S_{10} \rightarrow S_{0 v}(v=0$ 4) electronic transitions. ${ }^{45}$ The maxima of the four main peaks are at $482-485,502-505,525-$ 528, and 548-552 nm, the most blue-shifted values being for 4 and the most red-shifted for 3. Uranyl emission of 7 appears to be largely quenched, either through preferential absorption of the $420 \mathrm{~nm}$ radiation by $\mathrm{Ni}^{\mathrm{II}},{ }^{46}$ or through the latter providing a route for energy transfer and nonradiative relaxation, as frequently observed with d-block metal cations. ${ }^{47-52}$ The large, most intense peaks in 7 have maxima at about 484, 504 and $~ 522 \mathrm{~nm}$. Uranyl cations in complexes $\mathbf{4}$ and $\mathbf{5}$ have six oxygen atoms as equatorial donors, and $\mathbf{3}$ has four oxygen and two nitrogen donors, and the maxima positions in their spectra are in agreement with those generally observed in similar complexes, while the values for 7 , with five oxygen donors, are somewhat smaller than usual. ${ }^{53}$ Solid-state photoluminescence quantum yields (PLQYs) have been measured for complexes 3 and 4, and are 6 and 3\%, respectively. These are usual values for 
uranyl complexes having a pale yellow color, ${ }^{18,44}$ larger values, often associated with yellowgreen coloring, being still rare. ${ }^{54,55}$

\section{Conclusions}

Nine uranyl ion complexes with the diphenate ligand have been synthesized under solvohydrothermal conditions and characterized by their crystal structure. Although the coordination mode of the ligand displays some variability with combinations of $\kappa^{2} O, O^{\prime}$-chelation (mode 1 ), chelation involving both carboxylate groups (mode 2) and $\mu_{2}-\kappa^{1} O: \kappa^{1} O^{\prime}$ bridging mode, the assemblies formed are most often of low periodicity, i.e. either zero- or monoperiodic. The former is found when only two ligands chelating in mode 2 fashion are bound, giving a discrete mononuclear complex with the somewhat unusual square bipyramidal environment (complex 6), or with further bridging giving a dinuclear complex with coordinated nitrate preventing polymerization (complex 8). Monoperiodic coordination polymers are generated with a variety of coligands or counterions (complexes 1-5 and 7). The additional metal cations, when present, are either included as separate counterions $\left(\mathrm{Ni}^{\mathrm{II}}\right.$ in $\mathbf{6}, \mathrm{Cu}^{\mathrm{II}}$ in $\left.\mathbf{8}\right)$, bound to the coordination polymer in decorating fashion $\left(\mathrm{Ag}^{\mathrm{I}}\right.$ in $\left.\mathbf{5}\right)$, or an essential part of the polymer $\left(\mathrm{Ni}^{\mathrm{II}}\right.$ in $7, \mathrm{Cu}^{\mathrm{II}}$ in 9). Only one diperiodic network has been obtained, with the fes topology, in which diaxially carboxylate-bound $\mathrm{Cu}\left(R, S-\mathrm{Me}_{6} \mathrm{cyclam}\right)^{2+}$ groups unite uranyl dimers into chains which are further assembled through bridging by other uranyl cations (complex 9). It appears that the diphenate ligand, with its two ligating groups displaying insufficient divergence, offers little prospect for the synthesis of uranyl-containing triperiodic frameworks. The limited donor group divergence is reflected in the large, 9-membered chelate ring (mode 2) formed by dip $^{2-}$ in complexes $\mathbf{1}$ and 5-9, such a large size for a chelate being unusual in coordination chemistry in general but explicable here and in the case of the similar ligand 1,1'-diphenyl-2,2',6,6'tetracarboxylate ${ }^{13}$ by the diminished entropic barrier to chelation resulting from conformational 
restrictions. Whether this tendency might be exploited by the use of diphenate as a blocking group in mixed carboxylate complexes is a prospect perhaps worthy of further exploration.

\section{Conflicts of interest}

There are no conflicts of interest to declare.

\section{References}

1. K. X. Wang and J. S. Chen, Acc. Chem. Res., 2011, 44, 531.

2. M. B. Andrews and C. L. Cahill, Chem. Rev., 2013, 113, 1121.

3. T. Loiseau, I. Mihalcea, N. Henry and C. Volkringer, Coord. Chem. Rev., 2014, 266-267, 69.

4. J. Su and J. S. Chen, Struct. Bond., 2015, 163, 265.

5. P. Thuéry and J. Harrowfield, Dalton Trans., 2017, 46, 13660.

6. I. Mihalcea, N. Henry, T. Bousquet, C. Volkringer and T. Loiseau, Cryst. Growth Des., 2012, 12,4641 .

7. P. M. Cantos, L. J. Jouffret, R. E. Wilson, P. C. Burns and C. L. Cahill, Inorg. Chem., 2013, 52, 9487.

8. P. Thuéry and J. Harrowfield, Inorg. Chem., 2015, 54, 8093.

9. E. A. Dolgopolova, O. A. Ejegbavwo, C. R. Martin, M. D. Smith, W. Setyawan, S. G. Karakalos, C. H. Henager, H. C. zur Loye and N. B. Shustova, J. Am. Chem. Soc., 2017, 139, 16852.

10. S. L. Hanna, X. Zhang, K. I. Otake, R. J. Drout, P. Li, T. Islamoglu and O. K. Farha, Cryst. Growth Des., 2019, 19, 506.

11. R. Zhao, L. Mei, L. Wang, Z. F. Chai and W. Q. Shi, Inorg. Chem., 2016, 55, 10125.

12. P. Thuéry and J. Harrowfield, Cryst. Growth Des., 2017, 17, 2116. 
13. P. Thuéry and J. Harrowfield, Inorg. Chem., 2015, 54, 6296.

14. Z. R. Qu, Wuji Huaxue Xuebao (Chin. J. Inorg. Chem.), 2007, 23, 2123.

15. P. Thuéry and B. Masci, CrystEngComm, 2012, 14, 131.

16. R. Zhao, L. Mei, K. Q. Hu, L. Wang, Z. F. Chai and W. Q. Shi, Eur. J. Inorg. Chem., 2017, 1472.

17. P. Thuéry and J. Harrowfield, Cryst. Growth Des., 2018, 18, 5512.

18. P. Thuéry, Y. Atoini and J. Harrowfield, Inorg. Chem., 2019, 58, 567.

19. R. W. W. Hooft, COLLECT, Nonius BV: Delft, The Netherlands, 1998.

20. Z. Otwinowski and W. Minor, Methods Enzymol., 1997, 276, 307.

21. G. M. Sheldrick, Acta Crystallogr., Sect. A, 2015, 71, 3.

22. G. M. Sheldrick, Acta Crystallogr., Sect. C, 2015, 71, 3.

23. L. J. Farrugia, J. Appl. Crystallogr., 2012, 45, 849.

24. K. Momma and F. Izumi, J. Appl. Crystallogr., 2011, 44, 1272.

25. V. A. Blatov, A. P. Shevchenko and D. M. Proserpio, Cryst. Growth Des., 2014, 14, 3576.

26. M. A. Spackman and D. Jayatilaka, CrystEngComm, 2009, 11, 19.

27. S. K. Wolff, D. J. Grimwood, J. J. McKinnon, M. J. Turner, D. Jayatilaka and M. A. Spackman, CrystalExplorer; University of Western Australia: Crawley, Australia, 2012.

28. R. Taylor and O. Kennard, J. Am. Chem. Soc., 1982, 104, 5063.

29. G. R. Desiraju, Acc. Chem. Res., 1996, 29, 441.

30. A. L. Spek, Acta Crystallogr., Sect. D, 2009, 65, 148.

31. P. Thuéry and J. Harrowfield, CrystEngComm, 2016, 18, 3905.

32. S. W. An, L. Mei, C. Z. Wang, C. Q. Xia, Z. F. Chai and W. Q. Shi, Chem. Commun., 2015, 51, 8978.

33. S. W. An, L. Mei, K. Q. Hu, F. Z. Li, C. Q. Xia, Z. F. Chai and W. Q. Shi, Inorg. Chem., 2019, 58, 6934. 
34. M. C. Etter, J. C. MacDonald and J. Bernstein, Acta Crystallogr., Sect. B, 1990, 46, 256.

35. J. Bernstein, R. E. Davis, L. Shimoni and N. L. Chang, Angew. Chem. Int. Ed., 1995, 34, 1555.

36. C. R. Groom, I. J. Bruno, M. P. Lightfoot and S. C. Ward, Acta Crystallogr., Sect. B, 2016, 72, 171.

37. R. Taylor and P. A. Wood, Chem. Rev., 2019, 119, 9427.

38. A. Whiteside, S. S. Xantheas and M. Gutowski, Chem. Eur. J., 2011, 17, 13197.

39. T. G. Mitina and V. A. Blatov, Cryst. Growth Des., 2013, 13, 1655.

40. P. Thuéry, Inorg. Chem., 2013, 52, 435.

41. P. Thuéry and J. Harrowfield, Inorg. Chem., 2017, 56, 1455.

42. P. Thuéry and J. Harrowfield, Eur. J. Inorg. Chem., 2017, 5451.

43. P. Thuéry, Y. Atoini and J. Harrowfield, Inorg. Chem., 2018, 57, 6283.

44. P. Thuéry, Y. Atoini and J. Harrowfield, Dalton Trans., 2019, 48, 8756.

45. A. Brachmann, G. Geipel, G. Bernhard and H. Nitsche, Radiochim. Acta, 2002, 90, 147.

46. P. Thuéry, Y. Atoini and J. Harrowfield, Inorg. Chem., 2019, 58, 870.

47. H. D. Burrows, S. J. Formosinho, M. da G. Miguel and F. Pinto Coelho, J. Chem. Soc., Faraday Trans. 1, 1976, 72, 163.

48. A. T. Kerr and C. L. Cahill, Cryst. Growth Des., 2014, 14, 1914.

49. A. T. Kerr and C. L. Cahill, Cryst. Growth Des., 2014, 14, 4094.

50. J. A. Ridenour, M. M. Pyrch, Z. J. Manning, J. A. Bertke and C. L. Cahill, Acta Crystallogr., Sect. C, 2017, 73, 588 .

51. A. T. Kerr, J. A. Ridenour, A. A. Noring and C. L. Cahill, Inorg. Chim. Acta, 2019, 494, 204.

52. G. E. Gomez, J. A. Ridenour, N. M. Byrne, A. P. Shevchenko and C. L. Cahill, Inorg. Chem., $2019, \mathbf{5 8}, 7243$.

53. P. Thuéry and J. Harrowfield, Inorg. Chem., 2017, 56, 13464. 
54. J. Xie, Y. Wang, W. Liu, X. Lin, L. Chen, Y. Zou, J. Diwu, Z. Chai, T. E. Albrecht-Schmitt, G. Liu and S. Wang, Angew. Chem. Int. Ed., 2017, 56, 7500.

55. Y. Wang, X. Yin, W. Liu, J. Xie, J. Chen, M. A. Silver, D. Sheng, L. Chen, J. Diwu, N. Liu, Z. Chai, T. E. Albrecht-Schmitt and S. Wang, Angew. Chem. Int. Ed., 2018, 57, 7883. 
For Table of Contents Use Only

Zero-, mono- and diperiodic uranyl ion complexes with the diphenate dianion: influences of transition metal ion coordination and differential $\mathrm{U}^{\mathrm{VI}}$ chelation

Pierre Thuéry, Youssef Atoini and Jack Harrowfield

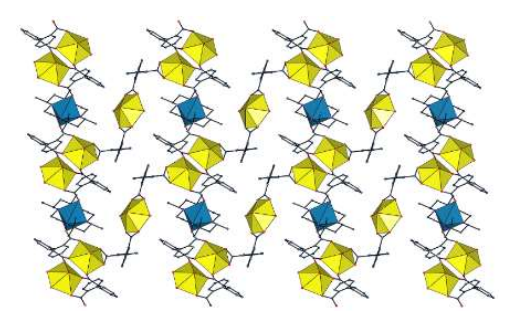

Diphenate complexes with uranyl cations are generally of low periodicity ( 0 or 1$)$, but for one 2-periodic uranyl-Cu $\mathrm{Cu}^{\mathrm{II}}$ species. 